\title{
China's Natural Gas Resource Potential and Production Trends
}

\subsection{Natural Gas Resource Potential}

\subsubsection{Resource Potential for Chinese Conventional and Unconventional Natural Gas}

According to estimates of China's natural gas resources, China's conventional and low-permeability natural gas geological resource volume amounts to 68 trillion $\mathrm{m}^{3}$, of which 40 trillion $\mathrm{m}^{3}$ is technically recoverable. Onshore conventional and low-permeability natural gas resources are primarily distributed in the three large basins of Sichuan, Erdos and Tarim. Marine natural gas resources are primarily distributed in the Pearl River Estuary, the South-East Qiong and the East Sea Basin.

From a systematic appraisal of 121 regions in 42 coal basins (groups), China's onshore coalbed methane resources located less than $2000 \mathrm{~m}$ underground amount to 36 trillion $\mathrm{m}^{3}$.

\footnotetext{
* This chapter was overseen by Zhonghong Wang from the Development Research Center of the State Council and Shangyou Nie from Shell International Exploration and Production. It was jointly completed by Xiaowei Xuan, Yingxie Yang, Yongwei Zhang, Jiaofeng Guo, Weiming Li, Beiqing Yao, Tao Hong and Yuxi Li from the State Resource Department Oil and Gas Centre, Xiaoli Liu from the National Development and Reform Commission's Energy Office, Guang Yang and Jianhong Yang from the China Energy Research Institute's Natural Gas Centre, Xiaobo Ju and Beijing Yao from Shell China. Other members of the topic group participated in discussions and revisions.
}

Technically recoverable resources less than $1500 \mathrm{~m}$ underground total 11 trillion $\mathrm{m}^{3}$. These are primarily distributed in China's northern Qinshui Basin, Erdos Basin, the YunnanGuizhou-Guangxi area and the Eastern Yunnan Western Guizhou Area. In terms of geologic sequence, they are primarily from the Carboniferous, Permian and Jurassic. According to national shale natural gas resource potential survey appraisals and the identification of the most promising regions, China's onshore shale natural gas geological resources located less than $4500 \mathrm{~m}$ underground total 134 trillion $\mathrm{m}^{3}$, with 25 trillion $\mathrm{m}^{3}$ of recoverable resources, primarily distributed in the Sichuan Basin and surrounding areas (Table 7.1).

China's gas hydrate resources are also very abundant, and are primarily distributed in the South China Sea and East China Sea regions, as well as in the permafrost of the Tibetan Plateau. Geological resources are approximately 102 trillion $\mathrm{m}^{3}$, and this is currently one of China's most abundant sources of clean energy, with the potential for large-scale development and the basic conditions in place to become a mainstream clean energy source (Table 7.2).

\subsubsection{Changes in Natural Gas Resource Assessments}

China has conducted five rounds of systematic national natural gas resource assessments. In 1986 the first round found that China's natural gas geological resource volume was 


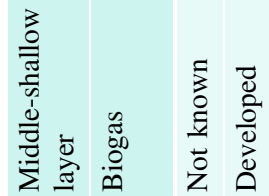

రٓ⿱艹

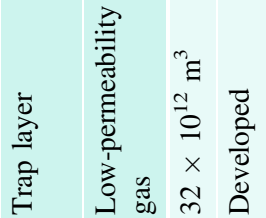

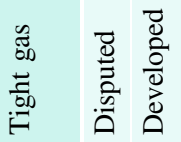

苞

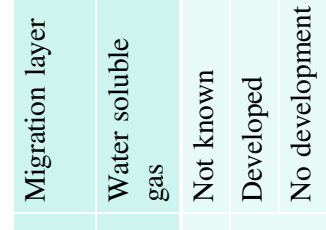

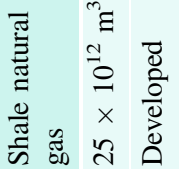

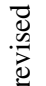

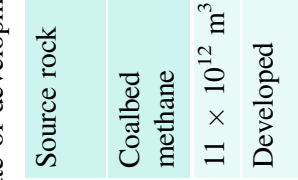

劳

ป

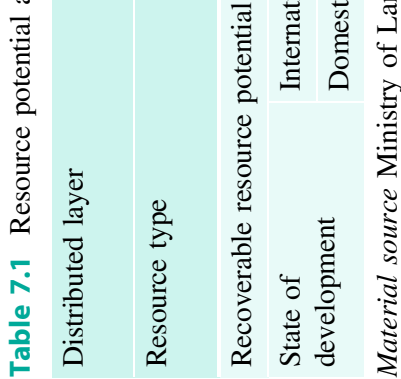
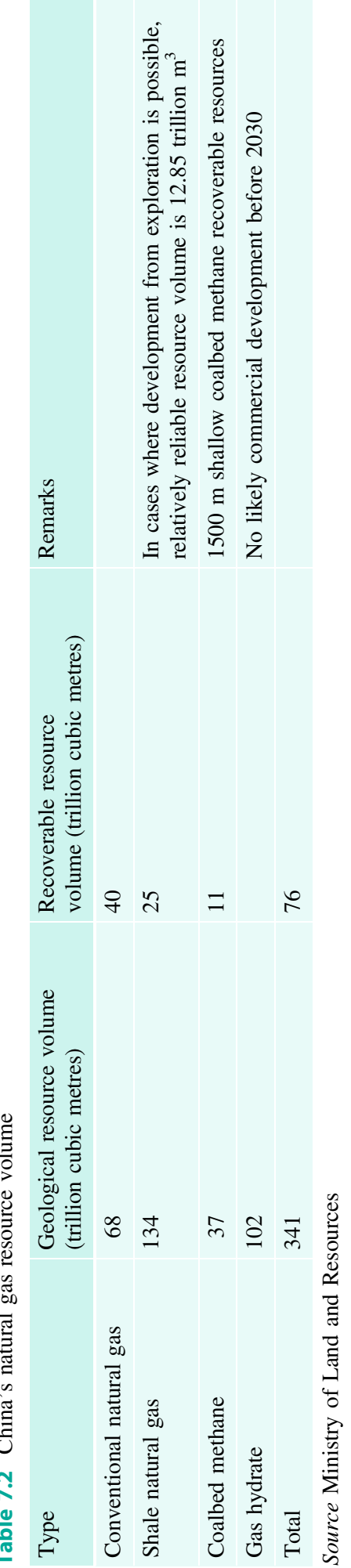
approximately 34 trillion $\mathrm{m}^{3}$. In 1994, the second round found that natural gas resources were $38 \mathrm{~m}^{3}$. In 2007, the third round found that, spread over 115 land and near-shore regions containing oil and gas basins, China's conventional natural gas resources were 35 trillion $\mathrm{m}^{3}$, with recoverable resources of 22 trillion $\mathrm{m}^{3}$. In 2012, the fourth round found that natural gas geological resources were 52 trillion $\mathrm{m}^{3}$, with recoverable resource volume of 32 trillion $\mathrm{m}^{3}$. The fifth round, in 2013, found that natural gas geological resources were further increased to 68 trillion $\mathrm{m}^{3}$, with recoverable resources rising to 40 trillion $\mathrm{m}^{3}$. In short, China's natural gas resource volume is continually increasing. This is especially clear from the 2013 results, which showed a marked increase over 2012 (Table 7.3).

Looking back at the history of exploration and development, it is clear that natural gas resources continually change along with the development of exploration. As demand continues to grow, natural gas exploration and development expands to satisfy it, with ever-increasing resource types and resource volumes. Progress in the development of oil and gas geological theory and technology is continually expanding the types of natural gas and their scope, generally pushing natural gas toward a trend of ever-expanding development. Also, the influence of price changes will cause short-term fluctuations in the amount of natural gas that is judged economically recoverable.

\subsection{Proved Natural Gas Reserves}

\subsubsection{Conventional Natural Gas}

China's natural gas exploration and development lagged behind oil, with generally low levels of exploration. According to BP's annual statistical review, since 2006, proved natural gas reserves have consistently maintained high rates of growth, with annual proved natural gas original reserve volumes of over 500 billion $\mathrm{m}^{3}$. Since 2010 , annual proved conventional natural gas geological
Table 7.3 China's historical natural gas resource assessment results

\begin{tabular}{|l|l|l|l|l|}
\hline Assessment time (years) & 1986 & 1994 & 2007 & 2012 \\
\hline \begin{tabular}{l} 
Geological resources (trillion cubic metres) \\
\hline Recoverable resources (trillion cubic metres)
\end{tabular} & 33.6 & 38.04 & 35 & 52 \\
\hline
\end{tabular}

Source Ministry of Land and Resources, Crude Oil Department and Oil and Natural Gas Headquarters materials

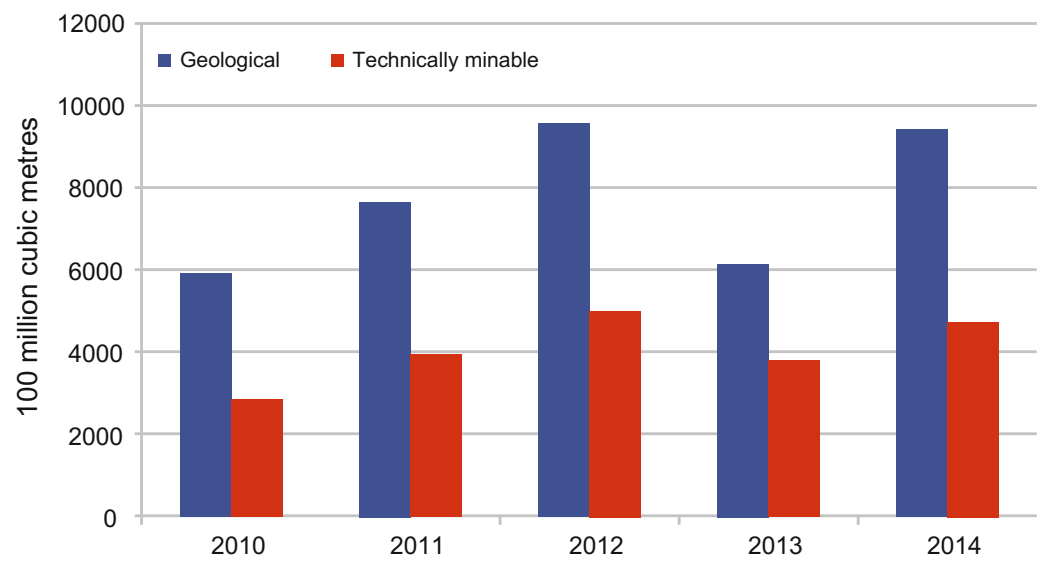

Fig. 7.1 China's annual increase in proved conventional natural gas reserves. Source Ministry of Land and Resources annual press conference materials 
reserves have exceeded 600 billion $\mathrm{m}^{3}$. Indeed, in 2012 and 2014, proved geological reserves were each nearly 1 trillion $\mathrm{m}^{3}$ (Fig. 7.1). Conventional proved natural gas reserves are primarily in the Tarim Basin, Sichuan Basin and Erdos Basin. In addition, deep within the Songliao Basin there has also been rapid growth in proved reserves. As of 2013, China's proved natural gas geological reserves were 9.66 trillion $\mathrm{m}^{3}$, with technically recoverable reserves of 5.54 trillion $\mathrm{m}^{3}$.

The basins in Sichuan, Erdos, Tarim, Songliao, Chaidamu and Zhungeer are now the six major mainland natural gas exploration areas. Ying-Qiong and the East China Sea have become the two major near-shore exploration areas, forming a basic layout of eight large natural gas exploration areas. Erdos, Sichuan and Tarim are the three major gas regions with reserves over 1 trillion $\mathrm{m}^{3}$.

China's proved natural gas reserve regions are relatively concentrated, and are primarily distributed in the western region, which accounts for $83 \%$ of resources, while the east region and offshore areas account for the other $17 \%$.

From 1986 to 1990 , proved natural gas source reserve growth was relatively small and less than 40 billion $\mathrm{m}^{3}$. In 1991-1995, growth was close to 100 billion $\mathrm{m}^{3}$, and in 1996-2000 growth was 150 billion $\mathrm{m}^{3}$. In 2001-2005, growth rose considerably to approximately 300 billion $\mathrm{m}^{3}$, while during 2006-2010, the growth was over 320 billion $\mathrm{m}^{3}$. In 2011-2013, conventional proved natural gas resources growth exceeded 600 billion $\mathrm{m}^{3}$ for three years in a row, with an additional 616.4 billion $\mathrm{m}^{3}$ added in proved conventional natural gas reserves in 2013. In 2014, newly added proved conventional geological reserves reached 943.7 billion $\mathrm{m}^{3}$, marking an increase of $53 \%$ year on year. Conventional proved natural gas volume increased consistently, setting a foundation for large natural gas production volumes.

\subsubsection{Coalbed Methane}

In 2012, national proved coalbed methane reserves added 134.4 billion $\mathrm{m}^{3}$, rising year on year by $2.5 \%$. In 2013 , national proved coalbed methane reserves added 23.6 billion $\mathrm{m}^{3}$ (Table 7.4). Proved coalbed methane geological reserves are 575.4 billion $\mathrm{m}^{3}$, with technically recoverable reserves of 285.0 billion $\mathrm{m}^{3}$, showing rapid growth in proved coalbed methane reserves. Three-quarters of coalbed methane reserves originate from Qinshui Basin, while one quarter is from the Erdos Basin, with proved reserves of coalbed methane relatively sparse in other areas.

In 2006, proved coalbed methane wells and developed wells numbered 1373, a figure which then increased rapidly, so that by 2014 there were 18,000 coalbed methane well drillings.

Over many years of exploration, the Qinshui Basin has become an especially large coalbed methane region, with 400 billion $\mathrm{m}^{3}$ of geological reserves. The eastern edge of the Erdos Basin has become a target gas region, with over 100 billion $\mathrm{m}^{3}$ of geological reserves, and the coalbed methane industry development has good foundations.

\subsubsection{Shale Natural Gas}

As of the end of 2013, China had not submitted proved reserves of shale natural gas. In June 2014, China's first proved shale natural gas reserves passed review and inspection by the relevant authorities. The proved reserve is located in Sinopec's Fuling Gas Field Jiaoshiba Region Coke-1 Well 3, over an area of $106.45 \mathrm{~km}^{2}$, and the layers incorporating shale natural gas are a Wufeng group within Longmaxi. Experts believe that the Lingpei Shale Gas Field is a typical shale natural gas field. The gas field reservoir layer is a marine deep-shelf quality shale with significant
Table 7.4 Coalbed methane newly added proved reserve data table

Time (year)
Proved geological reserves
$\left(100\right.$ million $\left.\mathrm{m}^{3}\right)$

\begin{tabular}{|l|l|l|l|l|l|}
\hline 2008 & 2009 & 2010 & 2011 & 2012 & 2013 \\
\hline 225 & 244 & 1299 & 1311 & 1344 & 236 \\
\hline
\end{tabular}

Source Ministry of Land and Resources annual press conference materials 
thickness and very high abundance. Distribution is stable, depth is suitable, and there are no intervening layers in between, markedly different from conventional gas deposits, and having the characteristics of typical shale natural gas, being similar to North American typical marine-shelf shale natural gas indicators. The Peling Shale Gas Field is a high-quality marine-shelf shale natural gas field that has excellent quality and quantity of resources. There is a high formational pressure, the natural gas components are good, gas well production volumes are high, and there have been good results seen from mining attempts. There has been a high production volume from pilot wells, with long periods of stable production. An expert appraisal panel has determined proved shale natural gas volume to be 106.5 billion $\mathrm{m}^{3}$.

As of June 30 2014, the Jiaoshiba region's 29 wells with pilot mining recorded total daily gas production of 3.2 million $\mathrm{m}^{3}$, with accumulated gas production of 611 million $\mathrm{m}^{3}$. As part of this, the first exploration well Coke IHF has recorded stable production for a year and a half at $60,000 \mathrm{~m}^{3}$ per day, with an accumulated gas production of 37.69 million $\mathrm{m}^{3}$.

\subsection{Growth of Natural Gas Production}

\subsubsection{Conventional Natural Gas}

Prior to 1995, China's natural gas production growth was slow, rising from 14.3 billion $\mathrm{m}^{3}$ in
1980 to 17.4 billion $\mathrm{m}^{3}$ in 1995 . From 1995 to 2005 , natural gas production accelerated, growing from 17.4 billion $\mathrm{m}^{3}$ to nearly 50 billion $\mathrm{m}^{3}$, an average annual growth of 3.2 billion $\mathrm{m}^{3}$. Since production reached 50 billion $\mathrm{m}^{3}$, annual average growth has been approximately 8 billion $\mathrm{m}^{3}$. By 2012 it had reached 107.2 billion $\mathrm{m}^{3}, 117.0$ billion $\mathrm{m}^{3}$ in 2013 and 128 billion $\mathrm{m}^{3}$ in 2014 , with net annual growth of $9.4 \%$ (Fig. 7.2). Since 2000, China's natural gas production volume growth has been approximately $9.6 \%$, and annual average growth for natural gas over the next 10 years or so is expected to be roughly $9-10 \%$.

Since 2007, conventional natural gas consumption volume has exceeded natural gas production volume, and natural gas imports have continually increased. By 2013, China's conventional natural gas consumption volume had reached 166 billion $\mathrm{m}^{3}$ (see Fig. 7.3). In recent years, natural gas consumption volume has grown by $12 \%$, markedly higher than natural gas production growth. Domestic natural gas production volume is still unable to meet the needs of domestic natural gas demand, with imports of natural gas continually increasing.

\subsubsection{Coalbed Methane}

China's coalbed methane production volume includes both extraction and coal mine well drainage. This research only deals with

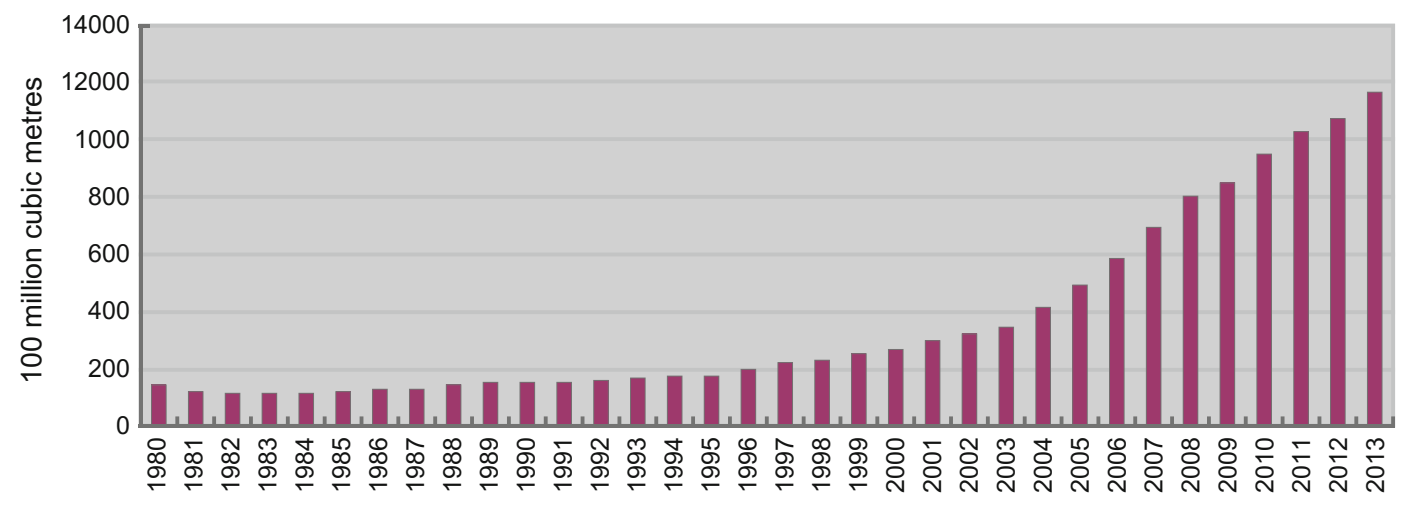

Fig. 7.2 Natural gas production volume in China. Source BP, 2014 


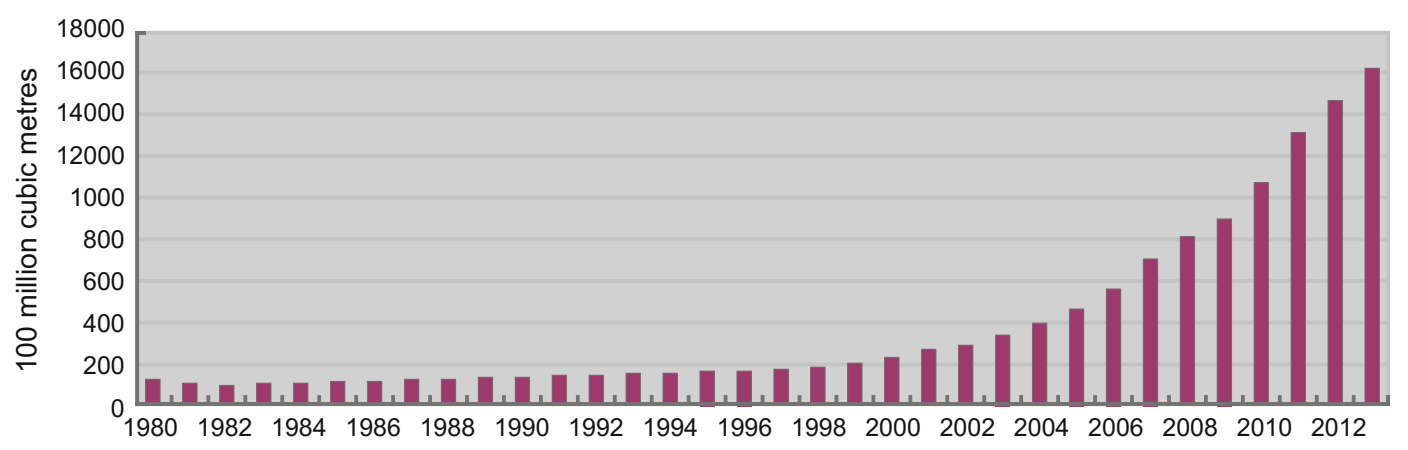

Fig. 7.3 Conventional natural gas consumption volume in China. Source BP, 2014

Table 7.5 China's coalbed methane production volume in recent years

\begin{tabular}{|l|l|l|l|l|}
\hline Time (year) & 2011 & 2012 & 2013 & 2014 \\
\hline Production volume $\left(100\right.$ million $\left.\mathrm{m}^{3}\right)$ & 23 & 25.7 & 29.3 & 36
\end{tabular}

Data source Ministry of Land and Resources annual press conference materials extraction-based coalbed methane, and does not consider well drainage coalbed methane. As of 2011, China's ground extracted coalbed methane was 2.3 billion $\mathrm{m}^{3}$, with 2012 ground extracted coalbed methane production volume of 2.57 billion $\mathrm{m}^{3}$, a growth of $13 \%$ year on year. Coal mine region coalbed methane production grew by $9.9 \%$ year on year, with the rate of growth dropping during the same period. By 2013, ground extracted coalbed methane production volume was 2.93 billion $\mathrm{m}^{3}$, growing by $13.7 \%$. In 2014 , ground extracted coalbed methane production volume was 3.6 billion, marking a large jump upward (Table 7.5).

As of 2012, there were seven constructed coalbed methane development projects, with eight development projects in progress. Ground development coalbed methane production capacity construction had reached 4.9 billion $\mathrm{m}^{3}$. In the past two years, new regions and new development projects have continually opened up, providing huge momentum for coalbed methane industry development. For example, the Baode 1 billion $\mathrm{m}^{3}$ production capacity construction, the Yanchuan South 500 million $\mathrm{m}^{3}$ production capacity construction, the Mi'nan Region East 1.5 billion $\mathrm{m}^{3}$ construction capacity construction and the Nanzhuang South 1 billion $\mathrm{m}^{3}$ construction plans are all under way.
Moreover, total production capacity of approximately 1.5 billion $\mathrm{m}^{3}$ will be developed through projects including Shouyang, Liulin, Changzi, Mabi and Shunan.

Coalbed methane exploration and development exhibits a marked trend toward new regions, new layers and new sectors:

- In recent years, coalbed methane exploration has continually seen breakthroughs at depths lower than 800-1000 m, with coalbed methane seeking relatively good single well production volumes. For example, in the Yanchuan Region at depths of 1497-1503 m, daily gas production has been relatively high at $3600 \mathrm{~m}^{3}$, while the Qinshui Basin in Zhengzhuang at a depth of $1337 \mathrm{~m}$ has achieved daily gas production of $2336 \mathrm{~m}^{3}$. Deep coalbed methane breakthroughs have resulted in a marked expansion in the exploration and development of coalbed methane.

- In recent years there have also been significant breakthroughs in low-rank coal exploration, for example, in Huainan single-well daily production volumes at $660-880 \mathrm{~m}$ have been $1000-2100 \mathrm{~m}^{3}$, Hui Chun has seen stable single-well production of $1500-2200 \mathrm{~m}^{3}$ at $450-550 \mathrm{~m}$ and Yilan has seen stable single-well production of $1000-1200 \mathrm{~m}^{3}$ at $700 \mathrm{~m}$ in depth. In addition, in Huolin River, 
Binchang and other places, low-rank coal regions have achieved production volumes of over $1000 \mathrm{~m}^{3}$. Breakthroughs in low-rank coal have opened up the door to development of coalbed methane in northern regions, where low-rank coal is distributed.

- Taking the Erdos Basin Hedong region as a representative of the North China Palaeozoic coal stratum, there are typical coalbed methane, tight natural gas and shale natural gas characteristics between the layers. However, comprehensive development of multiple types of natural gas resources has not yet seen a breakthrough. In recent years, the Hedong region has increased exploration efforts within the coal stratum seeking tight sandstone gas, with marked breakthroughs already achieved and $6000-50,000 \mathrm{~m}^{3}$ of production volume of tight natural gas already achieved, and individual well production volumes also higher.

\subsubsection{Shale Natural Gas}

In 2012 China released the Shale Gas Development Plan (2011-2015), in which there were plans that by 2015 proved shale natural gas reserve volumes would be 600 billion $\mathrm{m}^{3}$, with 200 billion $\mathrm{m}^{3}$ recoverable. In 2015 , shale natural gas production was expected to be 6.5 billion $\mathrm{m}^{3}$. Based on calculation of 115 billion $\mathrm{m}^{3}$ of natural gas as 100 million tons of oil, 6.5 billion $\mathrm{m}^{3}$ of shale natural gas is equivalent to 5.65 million tons of oil.

According to the latest information released by the Ministry of Land and Resources, in 2014 China's shale natural gas production volume was 1.3 billion $\mathrm{m}^{3}$. As part of this, Jiaoshiba shale natural gas production volume approached 1.08 billion $\mathrm{m}^{3}$, and shale natural gas production in Chuannan and other regions was 200 million $\mathrm{m}^{3}$. The main natural gas production layers were in section 1 of the WufengLongmaxi Formation.

From the perspective of exploration progress, China has achieved shale natural gas flow objectives in formations including the
Qiongzhusi Formation, Wufeng-Longmaxi Formation, Longtan-Dalong Formation, Yanchang Formation, Xujiahe Formation, Ziliujing Formation and others. Currently, only the Wufeng-Longmaxi Formation has achieved successful large-scale development, with other target formations still needing continual exploration.

\subsection{Conventional and Unconventional Natural Gas Production Forecasts}

According to current natural gas increase trends, forecasts for conventional and unconventional natural gas production are as follows.

\subsubsection{Production Volume Forecast}

\section{Forecasts based on the existing system}

Based on the annual average growth of natural gas production volume in the past several years of 8-10 billion $\mathrm{m}^{3}$, conventional natural gas annual average production volume is forecasted to be 8 billion $\mathrm{m}^{3}$. By 2020, conventional natural gas production volume will reach 180 billion $\mathrm{m}^{3}$. Based on target forecasts for shale natural gas production volumes from the Chongqing and Sichuan regions, by 2020 , shale natural gas production volume will be 40 billion $\mathrm{m}^{3}$. Coalbed methane production volume data primarily shows a trend for growth in the extraction of coalbed methane, and by 2020 this will reach around 10 billion $\mathrm{m}^{3}$. Production volume total for natural gas will be 230 billion $\mathrm{m}^{3}$ (not including coalbed methane) (Fig. 7.4).

\section{Forecast in a partially changed existing system}

With the system unchanged on the whole, and only conducting new system explorations for shale natural gas in Chuannan and Chuandong, achieving shale natural gas development in 


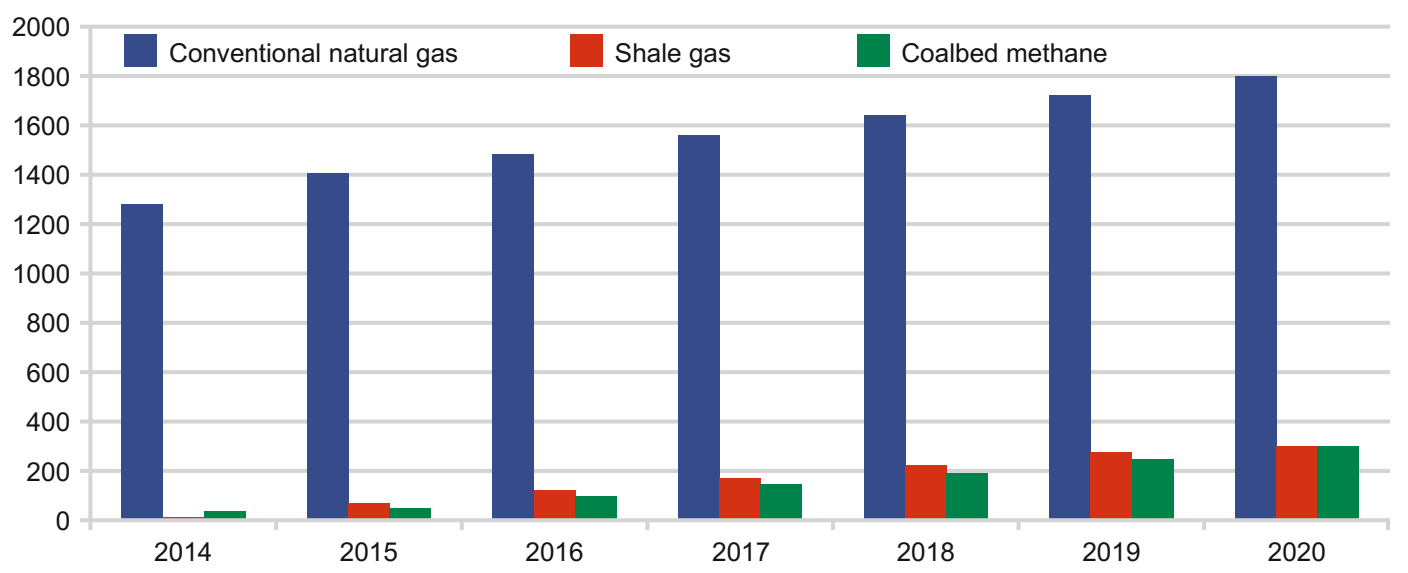

Fig. 7.4 Existing system natural gas production volume forecasts $\left(100\right.$ million $\left.\mathrm{m}^{3}\right)$

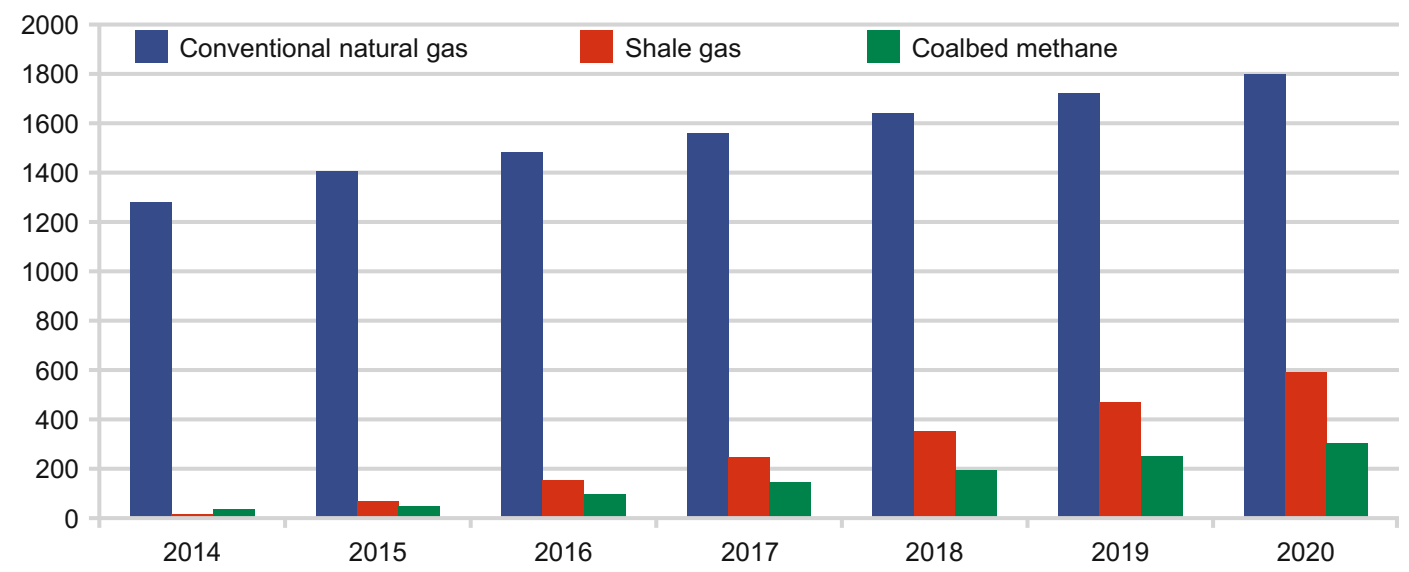

Fig. 7.5 Natural gas production forecasts in a partially adjusted system environment (100 million $\left.\mathrm{m}^{3}\right)$

general pilot regions for construction forecasts, conventional natural gas annual average growth will remain unchanged at 8 billion $\mathrm{m}^{3}$, and by 2020 will reach 180 billion $\mathrm{m}^{3}$. In Chuannan and Chuandong, if new system trials for shale natural gas development are conducted, by 2020 shale natural gas production volumes will be 60 billion $\mathrm{m}^{3}$. Coal formation coalbed methane and tight natural gas general development efforts will be strengthened, with forecasts that by 2020 , coalbed methane production volume will be 15 billion $\mathrm{m}^{3}$ and tight gas and shale gas production volume within coalbed methane areas will be 15 billion $\mathrm{m}^{3}$, for a total of 270 billion $\mathrm{m}^{3}$ (not including coalbed methane) (Fig. 7.5).

\subsubsection{Annual Production Forecast}

\section{Forecast in existing system}

From 2020 to 2030, conventional natural gas production annual growth rate will remain unchanged and maintain at 8 billion $\mathrm{m}^{3}$. By 2030, conventional natural gas production volume will be 260 billion $\mathrm{m}^{3}$. In Chuannan and Chuandong Longmaxi Formation, shale natural gas production volume will rise, with other shale natural gas formation production volumes also seeing breakthroughs. Shale natural gas production will rise from 40 billion $\mathrm{m}^{3}$ in 2020 to 80 billion $\mathrm{m}^{3}$. Ground-extracted coalbed 
methane production volume will reach 20 billion $\mathrm{m}^{3}$, while coal formation tight natural gas and shale natural gas production volume will reach 20 billion $\mathrm{m}^{3}$. Large-scale statistical coalbed methane production will be 40 billion $\mathrm{m}^{3}$, for a total of 280 billion $\mathrm{m}^{3}$ (not including coalbed methane).

\section{Forecast in a partially changed existing system}

If oil prices remain at the current normal level, enterprise natural gas profitability will rise, and enterprises will be more motivated to produce natural gas. If conventional proved natural gas reserves remain at a high level from 2010 to 2020, this will cause 2020-2030 annual production volume acceleration to rise slightly to 10 billion $\mathrm{m}^{3}$, and reach 280 billion $\mathrm{m}^{3}$ by 2030 . If Chuannan and Chuandong shale natural gas new system pilots are particularly effective, and if they are expanded to achieve commercial breakthroughs in other shale natural gas systems, then by 2030 shale natural gas production volume will reach 150 billion $\mathrm{m}^{3}$. Coalbed methane production volume will remain at 40 billion $\mathrm{m}^{3}$. Total natural gas production volume will be 470 billion $\mathrm{m}^{3}$ (not including coalbed methane).

China's natural gas production volume growth is controlled by myriad factors, including geological factors that can be resolved through technological progress. However, system and mechanism factors are also ubiquitous, and closely influence gains, and are difficult to resolve quickly. Cost factors in recent years have become an important factor affecting natural gas industry development, and since 2003 exploration and development costs have continually risen. If these cannot be effectively controlled, it will cause a marked influence on China's natural gas industry development and production volume goals. As a result, China's natural gas production volume increases could slow, and may be hard-pressed to exhibit explosive growth.

\subsection{Accelerating the Development of China's Domestic Natural Gas Resources}

\subsubsection{Clarify Development Paths}

Different paths of development require different policy measures. Given a clear development path, specific policy measures can be formulated to promote natural gas development.

\section{No change to the existing systems and mechanisms}

This path of development is an extension of the existing development paths. Based on State Council rules regarding oil and natural gas licensing, natural gas exploration, development and pipeline shipping will all be operated by existing state-owned oil companies. This business approach has the advantage of achieving intensive development of natural gas, and facilitates large-scale development. However, costs are also very high, and overall prices are somewhat excessive. This is especially true for prices in natural gas production regions, and supply markedly lags behind demand. For example, Sichuan, Chongqing, and Xinjiang natural gas prices and supply volumes have no marked advantage. Such a system causes cost increases for enterprises using natural gas as an energy source and source material.

\section{Using change to strengthen market guid- ance and diversify development}

Another path of development is to change the existing licensed operation system, and to use enhancements to market mechanisms to introduce multiple ownership system enterprises to develop natural gas and to carry out additional exploration, thus realising diversified development. Through market competition, the strongest and most competitive survive, carrying out new 
natural gas explorations, development projects and supply investments. This development approach requires that many issues are addressed, including high-quality preparation and fair allocation of mineral rights, the market liberalisation of oil and gas project services, the independent operation of natural gas pipelines and fair access to them, marketing and trading of proved reserves, and strong and effective oversight. Otherwise, major problems will arise that will destroy the market reforms.

It is suggested that existing systems and mechanisms are suitably adjusted, appropriately opening up conventional oil and gas operating rights by first opening up oil and gas mineral rights to large state-owned energy enterprises, such as state-owned energy enterprises that already hold shale natural gas mining rights, or opening up conventional oil and gas mining rights to energy enterprises that have already entered the oil and gas sector overseas, guiding these enterprises in their entry into domestic conventional and unconventional oil and gas exploration and development sectors.

\subsubsection{Adjust Lowest Exploration Commitments}

In 1996, China's Mine Law and subsequent accompanying legislation prescribed that oil and gas mine exploration rights holders had to invest at least $5000 \mathrm{CNY} / \mathrm{km}^{2}$ in the first year, $7000 \mathrm{CNY} / \mathrm{km}^{2}$ in the second year and $10,000 \mathrm{CNY} / \mathrm{km}^{2}$ in the third year. In the past, the low levels of exploration spending commitment did not take inflation into account. Because oil prices have gradually risen since 2003 , oil company exploration and development costs have also seen constant increase. Thus 10 years ago one exploration well only required $\mathrm{CNY}$ 3000-5000, whereas now CNY 10,000-20,000 might be needed to drill that same well, with some well fees being even higher.

Because of the steep increase in costs, maintaining such low exploration spending commitments has essentially led to annual declines in investment because of the changed price calculations. Previously, an CNY 100 million exploration commitment could drill three exploratory wells, whereas now only one can be completed for the same outlay. Physical exploration commitments by area are only one third to one fifth of their level 15 years ago. A large area abundant in natural gas may thus be seriously lacking in survey work, severely impacting natural gas discovery and reserve production growth.

Shale natural gas tender region bidding standards and management requirements have raised the conventional oil and gas region lowest exploration commitment by a factor of 3-5 from current levels, with each square kilometre having a lowest exploration commitment of CNY 30,000-50,000. An increase in the lowest exploration commitment will increase survey efficiency and promote prompt exits from regions, thus reducing the occupied area of various sectors and changing the current situation in which areas are marked out but not explored. At the same time, the current system of authorisation through advance application could be changed, following the example of the shale natural gas region transfer approach, which uses a competitive mode to transfer existing conventional oil and gas blocks. International conventions provide examples of how to formulate effective block exit mechanisms. A regulatory team should be set up to oversee implementation of legislation and systems.

\subsubsection{Maintain Reasonable Prices}

Currently, calls for natural gas price increases are very loud, demanding that natural gas be priced at $70 \%$ of oil prices according to heating value. As a basic energy and a source material for economic and social functioning, a natural gas price that is too high or too low is not beneficial to overall development of the economy. When the price is too low, producer investment momentum is insufficient and natural gas development is restricted. When natural gas prices are too high, this will keep a large quantity of potential consumers out of the market, which is 
not beneficial to the economic development of the nation as a whole. In recent years, low natural gas prices in the United States have played an important role in economic recovery, and this is worth taking into consideration.

In the past 10 years, China's natural gas reserve growth has been rapid, but production volume annual growth has been less than 10 billion $\mathrm{m}^{3}$. The reason for this is the gap between oil and natural gas heating value prices, especially with the existing special licensed operation system and high oil prices, which have made enterprises more willing to invest in oil production. Recently, oil price drops have caused oil and natural gas heating value pricing to become equivalent, and given China's relatively high natural gas price, oil companies have become more enthusiastic about the production of natural gas. In order to reach a natural gas price that both providers and buyers can accept in the market, the natural gas exploration and development market should be appropriately opened, and prices can then be formed through competitive mechanisms, thus establishing a relatively reasonable mechanism to set natural gas prices.

Different development mechanisms will result in different price-forming mechanisms. Therefore, natural gas price problems must be resolved after clarifying natural gas development mechanisms.

\subsubsection{Establish Trade Mechanisms and Trade Platforms for Proved Natural Gas Reserves}

In recent years, China's annual average proved natural gas geological reserves have consistently exceeded 500 billion $\mathrm{m}^{3}$, and it is expected that this will continue to grow fast for the next few years. However, proved reserves have not been promptly developed, and some have even remained undeveloped for long periods of time. The reason for this is partly due to that portion of proved reserves lacking effective economic momentum.
It is recommended that a trade mechanism be established for proved and difficult-to-utilise reserves, permitting this portion of reserves to enter the market and be transferred. This will allow them to reach the hands of enterprises that can economically effectively develop such resources and thus achieve prompt development and exploration. In such a system, enterprises can transfer proved reserves to recover their exploration costs, while development enterprises can purchase reserves to obtain development opportunities. In order to guarantee the prompt development of these reserves, it is important to avoid simple circulation and non-development of reserves.

\subsubsection{Accelerate Development of Unconventional Natural Gas}

China has abundant unconventional natural gas resources, of which shale natural gas and coalbed methane are independent mine types, and are the focus of unconventional natural gas development. Shale natural gas can be developed rapidly, and success has already been seen in Chongqing Fuling Jiaoshiba, with a breakthrough also seen in Chuannan region, where success was realised within a single year.

\section{Pilot zones for shale natural gas develop- ment in Chuannan and Chuandong}

Since 2009, when CNPC deployed and implemented its Wei 201 Well and formally began shale natural gas exploration, shale natural gas production volume reached 1.3 billion $\mathrm{m}^{3}$ by 2014. This demonstrates that shale natural gas is quick to enter production, quick to achieve efficiency and quick to develop.

The shale natural gas formation in the southern and eastern portions of the Sichuan Basin is the Longmaxi Formation. Based on CNPC and Sinopec shale natural gas resource assessment results, this shale natural gas formation has shale 
natural gas geological resource volume of 1.9 billion $\mathrm{m}^{3}$ in Chuannan and Chuandong, with recoverable resources of 4.5 trillion $\mathrm{m}^{3}$. Shale natural gas presents relatively low development risks, and has resource foundations and technical foundations to carry out scaled development.

Chuannan and Chuandong Longmaxi Formation are important areas when it comes to allowing shale natural gas to break through to large-scale production. Based on annual production of 60 billion $\mathrm{m}^{3}$ by 2020 , and calculating for stable production for 30 years, 1.8 trillion $\mathrm{m}^{3}$ of shale natural gas recoverable resources are needed. It would only take a proportion of the 4.5 trillion $\mathrm{m}^{3}$ of recoverable shale natural gas resources in Chuannan and Chuandong to achieve that goal. This means that by developing the pilot construction in Chuannan and Chuandong, it will be possible to effectively mobilise the Longmaxi Formation to provide sufficient shale natural gas to meet the long-term goal of $60-100$ billion $\mathrm{m}^{3}$ of shale natural gas per annum by 2020 . At the same time, it is also possible to explore the direction which oil and gas system reform should take in the future using pilot regions here.

\section{Additional support to coalbed methane development}

Additional support for coalbed methane development could be provided with policies that encourage profitability in the sector, with the aim of reaping benefits for energy security and the environment.

The first goal of enterprises when they develop coalbed methane is to obtain coalbed methane commodities and to make profit. There is another major objective for surface and underground extraction of coalbed methane in coal mining regions though: to ensure coal mine safety and to reduce gas emissions. In many respects, obtaining the coalbed methane commodities is actually the secondary aim. These two different mindsets require correspondingly different policy measures.

- Coalbed methane development in coal mining areas is motivated by safety and environmental protection considerations. Working closely with coal mining and developers, plans need to be advanced by five years in order to deploy surface extraction suitably far ahead of well extraction, by deploying Laotang drainage and other coalbed methane projects.

- Policies that encourage and facilitate coalbed methane can harness independent enterprises to carry out coalbed methane extraction at scale across multiple mine sites. Policies, especially subsidies that promote coalbed methane development, are primarily directed at enterprises that directly use this portion of coalbed methane (gas).

- When not involved with coal mining, coalbed methane development is a commercial activity, and can be promoted by incentive-focused industrial policy. Some coalbed methane mining regions are not within coal planning regions and coal mining regions in the next 10-20 years. The coal mining in these regions is commercial coalbed methane development, and coal mining safety and environmental problems do not arise. Such activity should not enjoy the preferential policies applied to coalbed methane development in coal mining areas. It is sufficient simply to use the current preferential development policies in such cases.

It is worth noting that subsidy policies that lack a time limit will cause enterprises to develop a reliance on national subsidies, resulting in the coalbed methane industry remaining in an immature state of development for longer than would otherwise be the case, rather than developing healthily and robustly. 


\section{Case 1: Establishing a 100 billion $\mathrm{m}^{3}$ Shale Natural Gas General Pilot Region in the Sichuan Basin}

The current international oil price is low, and US shale oil and gas companies have suffered the impact of this and even been forced to apply for bankruptcy protection. Asian LNG spot prices are also trending lower. However, looking to the long term, supply shortages and high import prices will be the major problems faced by China's natural gas development. Shale natural gas development is still a strategic choice for China's natural gas development. The Sichuan Basin's abundant shale natural gas resources and favourable development conditions make it possible to carry out pilots to test general reforms strategies. By using optimised systems and mechanisms, a preliminary shale natural gas development can be scaled up and commercialised to achieve annual production of 100 billion $\mathrm{m}^{3}$ by 2025 in this large shale natural gas region. This is not only a strategic choice to increase secure domestic natural gas supply; it also represents an unusually attractive investment opportunity.

\section{Sichuan Basin has the basic condi- tions in place}

During multiple surveys of Sichuan and Chongqing, and after meetings with multiple investors and engineering technicians, and collecting opinions from the relevant experts regarding shale natural gas development resource conditions, technology, equipment, engineering, investments, applications, environmental loads and other factors, it is our opinion that with the appropriate system and policies, the Sichuan Basin will become a leading region for shale natural gas development in China. By 2025, this region could feasibly achieve 100 billion $\mathrm{m}^{3}$ of shale natural gas production volume. The reasons are outlined below.

\section{(I) Resource conditions are guaranteed} The Sichuan Basin's shale natural gas resources are abundant, and there are wide distributions of two marine shelves of substantially thick black shale. According to Sinopec data, total shale natural gas resources in the entire Longmaxi Formation and Qiongzhusi Formation amount to 40 trillion $\mathrm{m}^{3}$. Of this, the Longmaxi Formation marine shelf shale natural gas has a promising area of $75,000 \mathrm{~km}^{2}$ that has already seen development breakthroughs, with a shale natural gas resource volume of 25 trillion $\mathrm{m}^{3}$ and recoverable resources of 3.7 trillion $\mathrm{m}^{3}$. As part of this $75,000 \mathrm{~km}^{2}$, there are $35,000 \mathrm{~km}^{2}$ of shale natural gas resources whose conditions are superior and geological resources of nearly 14 trillion $\mathrm{m}^{3}$, with recoverable resources of 28 trillion $\mathrm{m}^{3}$. If development is only pursued in the high-quality shale natural gas area of $20,000 \mathrm{~km}^{2}$ of the Longmaxi Formation, beginning in 2015, the exploration and well layout planning could be completed and approximately 10,000 wells could be deployed within 2015-2025. By 2025, annual production of 100 billion $\mathrm{m}^{3}$ could be achieved. Moving forward, active wells would number around 800 , achieving stable production for 20 years. It could be said that as far as resource volume is concerned, Sichuan and Chongqing entirely satisfies the requirements to establish a region with annual production of 100 billion $\mathrm{m}^{3}$.

\section{(II) Development technology and equipment is assured}

Currently, China has preliminarily come to terms with shale natural gas geophysics, well drilling, well completion, pressure 
fracturing and other technologies, giving it the ability to drill shallow water wells of $3500 \mathrm{~m}$ as well as staged fracturing. Non-seismic geophysical prospecting identification and forecasting technology, wholly-mobile rail drills, large-scale fracturing vehicles (3000 model, 3500 model), construction environment protection technology and other factors are now at similar levels of advancement to those seen internationally, and breakthroughs have also been achieved in domestic bridge plug manufacture. Compared to internationally mature technologies, China now only has shortcomings in drill geological positioning, on-drill measurements and micrometre-nanometre structure and composition analysis. However, the majority of well-known oil services companies from abroad are now participating in China's shale natural gas development, and can provide vital technologies. Sinopec's Chongqing Fuling (Fuling) Shale Gas Field has entered commercial development, attesting to the fact that China's shale natural gas development technology is now up to par. In addition, China's shale natural gas core equipment, such as sets of drills, fracturing vehicle groups, well tools and accompanying project services, all have powerful capabilities, with existing domestic drill quantities and drill production capacities entirely meeting the requirements placed on well drilling quantities during construction and production stages.

\section{(III) Good mining efficiency, guaran- teed economic benefit}

As of November 30, 2014, Sinopec (Fuling) Region had completed fracturing test gas sites at 69 wells and obtained medium to high production of shale natural gas flows, with an average well test production volume of $320,000 \mathrm{~m}^{3}$ per day. Based on unhindered flow volume of $1 / 3,1 / 4$ and $1 / 5$ accompanying set production, average single well annual production volume is approximately 21.60 million $\mathrm{m}^{3}$ or higher, with average single well costs of CNY 80 million (including exploration, mining and shipping). Adding simple processing such as water extraction to this, well costs are less than $1.5 \mathrm{CNY} / \mathrm{m}^{3}$, whereas current shale natural gas well prices are $2.78 \mathrm{CNY} / \mathrm{m}^{3}$. If a national financial subsidy of $0.4 \mathrm{CNY} / \mathrm{m}^{3}$ is added in, the actual price is $3.18 \mathrm{CNY} / \mathrm{m}^{3}$, and single well annual revenue once production stabilises could reach CNY 68.688 million. In addition to Fuling Region's shale natural gas mining achieving commercial viability, in the Chuanning, Changning and Weiyuan region the shale natural gas is buried relatively deep, but shale natural gas and conventional gas overlap in distribution and both possess general economic value. The eastern Chongqing region and Western Hubei region shale natural gas areas also feature light oil, and the economic value of mining this is also relatively high. The economic success of the Sichuan Basin's shale natural gas development is guaranteed.

\section{(IV) Environmental controls can draw on experience elsewhere, and min- ing water is assured \\ Currently, the United States has over} 10,000 shale natural gas wells, and with the participation and oversight of regulators and the public, there have been no environmental incidents affecting society. The majority of the shale natural gas-producing layers in the Sichuan Basin are at over $2000 \mathrm{~m}$ in depth, and so long as casing work is handled appropriately or assurance measures are added (such as installing an encircling casing), fracturing water has no chance of permeating into the 
water table system. In terms of water usage, water usage volume for 100 billion $\mathrm{m}^{3}$ of gas is approximately 100 million $\mathrm{L}^{3}$ of water, which is $1.6 \%$ of the water usage of Sichuan Province. Since the Sichuan Basin has abundant water resources, these water resources are entirely assured. However, recently in the United States, including Texas, there have been reports of small earthquakes and other events caused by development of shale oil/gas that are worthy of public attention.

\section{A shale natural gas development pilot area should be established quickly}

Basing calculations on annual production of 100 billion $\mathrm{m}^{3}$, an investment of $\mathrm{CNY}$ 800 billion would be required during the construction and production period (20152025 well completion for around 10,000 wells). Based on the current system (relying only on CNPC's south-west branch companies and Sinopec's south-west branch companies to invest), capabilities are extremely limited. This is especially true for the Longwangmiao large gas field discovered by CNPC's south-west branch company, with reserves of over 400 billion $\mathrm{m}^{3}$, located in central Sichuan. Conventional gas field construction likewise requires a large quantity of investment into exploration and development. Therefore, there is a need for new ideas for shale natural gas development, and it is recommended that a general pilot zone for shale natural gas development be constructed in the Sichuan Basin and surrounding areas. With a controlled and safe environment, preliminary trials can be attempted, restructuring shale natural gas development using a new model, with new mechanisms and new rules. This will promote shale natural gas development and also offer new points of reference for China's oil and gas reforms so that successful experiences can be replicated and promoted. Important measures include:

\section{(I) Innovative mining rights manage- ment and market access management}

The first issue is mining rights management. Resources that the three major oil companies have not begun to produce, explore or are in the process of developing and exploring should be the subject of tenders. The second issue is market access. Not only should other state-owned enterprises be introduced, but also private enterprises and foreign investment enterprises. In terms of foreign investment enterprise entry, not only should large transnational corporations be introduced, but small and medium-sized oil and gas enterprises with abundant experience and innovative capabilities should also be enabled to enter. These enterprises have played a critical role in the shale oil and gas revolution in the United States. In terms of foreign investment access, so long as technical and environmental standards are met, and national security reviews are passed, foreign investment enterprises could enter in an independent fashion.

\section{(II) Make use of the economic advan-} tages offered by mixed ownership

CNPC and Sinopec have taken steps towards establishing new ownership paradigms, for example CNPC has established the Sichuan Changning Natural Gas Development Co., Ltd in Changning and Sinopec has established Chongqing Shale Gas Exploration and Development Co., Ltd in Chongqing, each of which is a mixed ownership company. Mixed ownership offers state assets, private assets and 
foreign assets the opportunity to enter the shale natural gas development sector. It is also beneficial to central government enterprises, enabling greater use of societal capital and more rapid development. With local state-owned asset participation, there is greater breadth for enabling resettling, road repairs and natural gas nearby utilisation. With private enterprise and foreign enterprise participation, company government can be improved, thus raising the level of mining efficiency and service. The next step in shale natural gas development mixed ownership reforms requires efforts in terms of corporate governance, strategic co-ordination and the division of labour and partnerships. In order to improve overall activity, it is not enough simply to overlook mechanism transitions to obtain monetary funds. Likewise, the sole focus should not be on bringing in mixed capital, while essentially refusing to allow outside investors to participate in the corresponding management and operational activity.

\section{(III) Exploring effective shale natural gas regulatory models}

It is possible to aim to create a pilot zone for policy systems, management standards, oversight rules and regulatory systems relating to shale natural gas exploration, development, storage, and shipping usage within 2-3 years, including information search and sharing platforms. In terms of environmental oversight, central government standards and policies should be established, with local organisations implementing the environmental regulation. The Ministry of Environment is in the process of researching the establishing of shale natural gas development assessment guidelines. These could be tested in this region, with a preliminary launch and implementation of national norms and standards for such aspects as land usage, vegetation restoration, water resource usage, waste water processing, waste processing, gas emissions, drilling and well completion. In terms of geological material and information sharing, comparison can be made to the United States' administrative legislation approach to the mandatory collection of shale natural gas geological information, thus establishing a geological engineering information management platform with government-controlled resource information. This will achieve information sharing and promote highly efficient development.

\section{Case 2: Chinese Coalbed Methane Production Volume Forecasts}

\section{Coalbed methane resources}

China has abundant coalbed methane resources, which are typically found in multiple coal basins with multiple coal formations and a wide variety of coal types and coalbed methane deposits. Due to the wide variance in the coal-containing basins in China, subsequent construction and restructuring is intense, resulting in a very complex geological environment for coalbed methane resource deposits in China. Coalbed methane resources are primarily distributed in China's north, north-west, south and north-east regions.

China's proved coalbed methane volumes have grown rapidly. In 2012, national proved coalbed methane reserves grew by 134.4 billion $\mathrm{m}^{3}$, rising year on year by $32.2 \%$. In 2013 , national coalbed methane exploration proved new reserves of 23.577 billion $\mathrm{m}^{3}$. Proved coalbed methane geological reserves now sit at 575.4 billion $\mathrm{m}^{3}$, with technically recoverable reserves of 285 billion $\mathrm{m}^{3}$.

The regions that are abundant in coalbed methane are primarily the Qinshui Basin, the Erdos Basin and the Yunnan Guizhou North Depression. In 2012, new proved geological reserves in the Qinshui Basin 
were 90.242 billion $\mathrm{m}^{3}$, with the Erdos Basin newly adding proved coalbed methane reserves of 37.11 billion $\mathrm{m}^{3}$. The Yunnan Guizhou North Depression in 2012 deployed and implemented 11 assessment wells and three well groups, for a total of 18 wells as production capacity experiments. A total of 17 wells have achieved coalbed methane flows, with single well daily production capacity of $500 \mathrm{~m}^{3}$.

\section{Coalbed methane reserve forecasts}

\section{(I) Characteristics of coalbed methane-intensive regions in China}

Coal layer gas factors are generally assessed by usage of gas per ton of coal, absorption saturation, concentration of methane and resource abundance. Gas per ton of coal is gas volume, and is a determining factor in coalbed methane resource quantity. Resource abundance is a general reflection on the amount of gas in the coal and the thickness of the coal layer. Absorption saturation is a gas volume factor related to gas mining feasibility. Methane concentration is a major standard in assessing gas quality.

Regarding regional distribution, average coalbed methane gas volume is highest in southern China, followed by the north-east regions and northern China. The north-west region has the lowest amounts. The methane concentrations of each region are similar, and from highest to lowest are: southern China, northern China, the north-west and the north-east. The average resource abundance in each region varies significantly, with the north-west region markedly higher than other regions, followed by the north-east. Northern China is slightly lower than eastern China, with southern China the lowest. Average absorption saturation is led by north-east China, followed by southern China, northern China and the north-west.
From the perspective of coalbed methane layers, the Permo-Carboniferous, upper Permian series and Lower and Middle Jurassic series are representative of good gas contents. Other eras are relatively poor. From a general analysis, the northern region's major basins have good gas contents in the Permo-Carboniferous, and this is the primary gas layer for important basins.

From the perspective of coal rank distribution, the resource volume of high coal rank lean anthracite III ( $\mathrm{Ro}=1.9-2.5 \%)$ is 7.8 trillion $\mathrm{m}^{3}$, accounting for $21.1 \%$. The resource volume of medium-rank gas/lean coal $(\mathrm{Ro}=0.7-1.9 \%)$ is 14.3 trillion $\mathrm{m}^{3}$, accounting for $38.9 \%$. Low coal rank brown-long flame coal (Ro $<0.7 \%$ ) resource volume is 14.7 trillion $\mathrm{m}^{3}$, and accounts for $40 \%$.

\section{(II) Key target areas for coalbed methane exploration}

Based on summarising coalbed methane abundance patterns and gas characteristics, there are 18 target regions that have been selected nationwide as preferential locations, including Pucheng, Ji CountyHancheng, Shenmu, Hengshanbao, Ningwunan, Panguan, Gemudi, Pingle, Changji, Dajing, Wuermu, Wushenqi, Sanjiang-Mulinghe, Huolinhe and Yimin. Of these, six are Class I target regions, five are Class II target regions and seven are Class III target regions, giving a total area of $54,700 \mathrm{~km}^{2}$. The target Class I coalbed methane resource volume for the region is 3.63 trillion $\mathrm{m}^{3}$, primarily distributed in the Qinshui, Erdos, Zhunge'er and Ningwu basins. Coalbed methane geological conditions are good, representing coalbed methane near- and mid-term reserve and production volume realisation target areas. Class II and Class III areas have a total of 2.87 trillion $\mathrm{m}^{3}$ of resource volume, and are distributed across Tuha, Santanghu, Sanlian Basin, eastern Yunnan and Western Guizhou, and the Pingle Basin, and 
have potential for mid- to long-term reserve growth and subsequent replacement blocks. As part of this, the Qinshui Basin south portion Jincheng region, Erdos Basin south-east region Ji CountyHancheng region, and the Zhunge'er Basin south-east Changji-Dajing are promising coalbed methane regions with reserves of 100 billion $\mathrm{m}^{3}$ (Table 7.6).

This research is based on national coalbed methane reserve historical data, in conjunction with coalbed methane geological characteristics and resource distribution traits, making use of the Weng model method and Gompertz method to forecast proved coalbed methane reserves and production volume. It is expected that by the end of the 12th Five-Year Plan, 10 advantageous target regions will see newly added proved geological reserves of 700 billion $\mathrm{m}^{3}$. During the period of the 13th Five-Year Plan, the scope of explorations will be further expanded to south
China, and the north-east and north-west regions, with newly added proved reserves of 350 billion $\mathrm{m}^{3}$ in the Qinshui Basin, Erdos Basin, Zhunge'er Basin, Ningwu Basin and Erlian Basin. From 2013 to 2030, annual proved reserves will be at approximately 100 billion $\mathrm{m}^{3}$. After 2030 , as coalbed methane exploration and development technology continues to progress, coalbed methane at $2000-4000 \mathrm{~m}$ will also be possible to confirm and mine, with large increases in proved reserves expected in coalbed methane (Table 7.7).

\section{(III) Coalbed methane production vol- ume forecasts}

As coalbed methane exploration and development technology matures and mining costs drop, coalbed methane development will become larger-scale and will develop toward greater industrialisation, gradually forming $10-15$ coalbed methane production bases. Using the Weng

Table 7.6 National coalbed methane results of selection of favourable target regions

\begin{tabular}{|c|c|c|c|c|c|c|c|}
\hline Class & Basin & Region & $\begin{array}{l}\text { Major } \\
\text { depth (m) }\end{array}$ & $\begin{array}{l}\text { Major coal } \\
\text { thickness } \\
\text { (m/layer) }\end{array}$ & $\begin{array}{l}\text { Gas } \\
\text { contents } \\
\left(\mathrm{m}^{3} / \mathrm{t}\right)\end{array}$ & $\begin{array}{l}\text { Area } \\
\left(\mathrm{km}^{2}\right)\end{array}$ & $\begin{array}{l}\text { Resource } \\
\text { volume } \\
\left(10^{8} \mathrm{~m}^{3}\right)\end{array}$ \\
\hline \multirow[t]{6}{*}{ I } & Qinshui & Qinshui north & $200-1200$ & $8-17 / 2$ & $10-32$ & 5150 & 11,864 \\
\hline & Erdos & Erdos east & $300-1500$ & $7-22 / 2-3$ & $9-20$ & 7430 & 11,805 \\
\hline & Zhunge'er & Changji-Fukang & $300-1000$ & $25-32 / 3$ & $5-15$ & 7010 & 7460 \\
\hline & Qinshui & Yangquan-Heshun & $150-1300$ & $9-12 / 2-3$ & $8-35$ & 1200 & 2500 \\
\hline & Ningwu & Ningwu south & $800-1500$ & $11-14 / 1$ & $11-21$ & 534 & 1665 \\
\hline & Sanlian & Huolinhe & $300-900$ & $7-34 / 5$ & $5-8$ & 380 & 1025 \\
\hline
\end{tabular}

Data source Ministry of Land and Resources and other material analysis and preparation

Table 7.7 National proved coalbed methane reserve forecast $\left(100\right.$ million $\left.\mathrm{m}^{3}\right)$

\begin{tabular}{|l|l|r|r|r|}
\hline & 2015 & \multicolumn{1}{|c|}{2020} & \multicolumn{1}{c}{2025} & \multicolumn{1}{c}{2030} \\
\hline New proved geological reserves & 7000 & 3500 & 4800 & 7200 \\
\hline Accumulated proved reserves & 8619 & 12,119 & 16,919 & 24,119
\end{tabular}

Data source Ministry of Land and Resources and other material analysis and preparation 
Table 7.8 National coalbed methane production growth forecasts $\left(100\right.$ million $\left.\mathrm{m}^{3}\right)$

\begin{tabular}{|l|l|l|l|}
\hline & 2015 & 2020 & 2030 \\
\hline Production volume & 45 & $100-300$ & 400
\end{tabular}

Data source Ministry of Land and Resources and other material analysis and preparation

model and the Gompertz method to analyse China's future coalbed methane production volume growth, it is expected that 2015 coalbed methane production volume will be 4.6 billion $\mathrm{m}^{3}$, rising to $10-30$ billion $\mathrm{m}^{3}$ by 2020 . From 2021 to 2030, 20-30 coalbed methane production bases will be established, with 40 billion $\mathrm{m}^{3}$ of production volume by 2030 (Table 7.8).

\section{Case 3: Forecast of China's Coal Methane Production Potential}

\section{Coal methane development}

With the implementation of a sustainable development strategy and the strengthening of environmental and other policies, domestic natural gas consumption markets are continually expanding, and there are more channels and more methods of expanding the natural gas resource supply, and optimising the gas source structure has become an important strategic part of optimising the national energy structure. Converting coal region resources into natural gas can to a certain degree supplement China's shortage of conventional natural gas supply.

China has approved its first two coal methane projects: Keqi, with coal methane production capacity of 4 billion $\mathrm{m}^{3} / \mathrm{year}$, divided into three series, with each series having production capacity of 1.33 billion $\mathrm{m}^{3}$; and Qinghua, with 5.5 billion $\mathrm{m}^{3} /$ year, divided into four stages of construction. The first stage has production capacity of 1.375 billion $\mathrm{m}^{3} /$ year. In 2013 the two coal methane projects in total had gas volume of 31 million $\mathrm{m}^{3}$.

Approved and in-progress coal methane projects include the Fuxin and Huineng coal methane projects, with total production capacity in the region of 5.6 billion $\mathrm{m}^{3} /$ year, and expectations to begin gas supply in 2015. In-progress and operating coal methane projects are listed in Table 7.9.

Table 7.9 Operating and in-progress coal methane projects

\begin{tabular}{|c|c|c|c|c|}
\hline Type & Project name & $\begin{array}{l}\text { Date of } \\
\text { operation }\end{array}$ & Scale & $\begin{array}{l}\text { Total production capacity } \\
\left(100 \text { million } \mathrm{m}^{3}\right)\end{array}$ \\
\hline \multirow[t]{2}{*}{ In operation } & Datang Keqi Coal Methane Project & 2013 & 13.3 & 40 \\
\hline & Xinjiang Qinghua Coal Methane Project & 2013 & 13.75 & 55 \\
\hline \multirow{3}{*}{$\begin{array}{l}\text { Under } \\
\text { construction }\end{array}$} & Huineng Coal Methane Project & 2015 & - & 16 \\
\hline & $\begin{array}{l}\text { Liaoning Datang Fuxin Coal Methane } \\
\text { Project }\end{array}$ & 2015 & - & 40 \\
\hline & $\begin{array}{l}\text { Inner Mongolia Shenhua Erdos Coal } \\
\text { Methane Project }\end{array}$ & 2015 & - & 20 \\
\hline Total & & 27.05 & 171 & \\
\hline
\end{tabular}

Data source Public materials analysis and organisation 


\section{Progress in coal methane project planning and construction}

In recent years, China has seen an acceleration in approvals of coal methane projects, primarily concentrated in Inner Mongolia and Xinjiang. As of the end of June 2014, the NDRC had approved 18 coal methane projects, with a combined production capacity of 84.2 billion $\mathrm{m}^{3} /$ year. Provincial planning and filing showed 37 projects with production capacity scale of 129.6 billion $\mathrm{m}^{3} /$ year. Operating projects, or those with road permits and approvals, as well as those under construction, had a total production capacity of 230.9 billion $\mathrm{m}^{3} / \mathrm{year}$. Currently, only a small number of these projects have begun construction, and considering that current natural gas prices are a problem, as well as the current policy environment, not all projects will necessarily be finished. It is also not a given that the completed projects will be able to satisfy the load of production, but production capacity will still offer basic assurances for China's natural gas supply security (Table 7.10).

Table 7.10 China's current coal methane projects with road permits

\begin{tabular}{|c|c|c|c|}
\hline No. & Province & Project name & $\begin{array}{l}\text { Production capacity } \\
\left(100 \text { million } \mathrm{m}^{3} / \text { year }\right)\end{array}$ \\
\hline 1 & $\begin{array}{l}\text { Inner } \\
\text { Mongolia }\end{array}$ & Xinmeng Energy Investment Co., Ltd Coal Methane Project & 40 \\
\hline 2 & $\begin{array}{l}\text { Inner } \\
\text { Mongolia }\end{array}$ & $\begin{array}{l}\text { Erdoa Coal Methane Industrial Park and } 12 \text { billion } \mathrm{m}^{3} \text { Coal } \\
\text { Methane Project }\end{array}$ & 120 \\
\hline 3 & $\begin{array}{l}\text { Inner } \\
\text { Mongolia }\end{array}$ & State Grid Inner Mongolia Guxinganmeng Coal Methane Project & 40 \\
\hline 4 & $\begin{array}{l}\text { Inner } \\
\text { Mongolia }\end{array}$ & Huaneng Yimin Coal Methane Project & 40 \\
\hline 5 & $\begin{array}{l}\text { Inner } \\
\text { Mongolia }\end{array}$ & Inner Mongolia China Star Energy Limited Coal Methane Project & 40 \\
\hline 6 & Xinjiang & Huaneng Xinjiang Coal Methane Project & 40 \\
\hline 7 & Xinjiang & $\begin{array}{l}\text { China Power Investment Corporation Xinjiang Huocheng Coal } \\
\text { Methane Project (three phases) }\end{array}$ & 60 \\
\hline 8 & Xinjiang & Xinjiang Fuyun Guanghui Coal Methane Project & 40 \\
\hline 9 & Xinjiang & China Coal Energy Xinjiang Coal Methane Project & 40 \\
\hline 10 & Xinjiang & State Grid Pingmei Coal Methane Project & 40 \\
\hline 11 & Xinjiang & Xinjiang Longyu Coal Methane Project & 40 \\
\hline 12 & Xinjiang & Huadian Xinjiang Coal Methane Project (Xiheishan coal methane) & 40 \\
\hline 13 & Xinjiang & Sinopec Great Wall Energy Coal Methane Project & 80 \\
\hline 14 & Xinjiang & Xinjiang Yili Xintian Coal Methane Project (Xinwen phase one) & 20 \\
\hline 15 & Xinjiang & Suxin Energy Xinjiang Coal Methane Project & 40 \\
\hline 16 & Xinjiang & CPCEC Yinan Coal Methane Project (three phases) & 60 \\
\hline 17 & Shanxi & CNOOC Shanxi Datong Coal Methane Project & 40 \\
\hline 18 & Anhui & Anhui Huai'nan Coal Methane Project & 22 \\
\hline \multicolumn{2}{|c|}{ Total } & & 842 \\
\hline
\end{tabular}

Data source Public materials analysis and organisation 


\section{Coal methane production potential analysis}

According to the construction progress of coal methane projects, and in conjunction with project construction cycles and production capacity plans, an arrangement has been made of all coal methane project production capacity.

Projects in 2020 with full road permits will have total production capacity of 84.2 billion $\mathrm{m}^{3} /$ year, and, considering they are based on three phases, with basic commencement post-2018, by 2020 it will be possible to achieve two-phase scaled capacity of 60 billion $\mathrm{m}^{3} / \mathrm{year}$, reaching 95 billion $\mathrm{m}^{3} /$ year in 2025 and 102 billion $\mathrm{m}^{3} /$ year in 2030 .

However, what is worthy of note is that, moving forward, coal methane development still faces many uncertainties. One factor is the currently relatively low international oil and natural gas prices, which have greatly inhibited the profit space for coal methane, especially given significant difficulties with project cost difficulties. A second factor is water consumption and environmental pollution, which causes significant controversy. Therefore, while coal methane production capacity will be built in the future, specific production capacity is nonetheless still highly uncertain.

\section{Case 4: Rural Organic Waste Natural Gas Effects and Policies}

It has been estimated that nearly $76 \%$ of organic waste in China comes from agriculture, with crop stalks and livestock manure being the two major sources. China's villages have 600 million tons of crop stalks dispersed among fields, and farmers generally deal with these by burning them, which is inefficient and not environmentally friendly. As livestock intensity becomes increasingly concentrated, concentrated processing of manure is a problem that not only hinders enterprise development but also endangers the rural environment. Resolving rural organic waste transitioning has always been one of the major issues facing agriculture. Beijing Deqingyuan has explored a series of technical models that transform rural organic waste into clean energy, and their experience is worthy of attention and wider promotion.

\section{Improving rural environments and changing rural energy usage structures}

Beijing Deqingyuan is an egg producer in Beijing that has won industry fame and market share by giving its eggs an "identity document" (using edible ink to print the brand name, production date and a fraud prevention code on each egg's shell). However, after they expanded their production scale, they discovered there were also attendant environmental problems, with 2 million laying hens producing the same amount of manure each day as 300,000 people. If this waste is not processed, it causes contamination to the groundwater and soil. To this end, Beijing Deqingyuan specially established a clean energy company to resolve the problem of transforming and using chicken manure. After several years of study, a breakthrough took place in the three technical areas of sand removal, high-concentration purity extraction and biological desulphurisation, achieving power generation from chicken manure methane in 2007. Following on from this, they next developed a mixed-source material production of methane gas from crop stalks and chicken manure, making natural gas after purification compression. The break 
throughs in these technologies have yielded feasible solutions to bring about rural organic waste transformation and to allow farming using renewable energy.

The first point to note is the improvements to organic waste conversion and to the rural environment. Deqingyuan can process 100,000 tons of manure per year, equivalent to reducing $\mathrm{CO}_{2}$ emissions by 71,000 tons, and 35 tons of nitrites. A total of 25,000 tons of crop stalks are processed annually, equivalent to a $\mathrm{CO}_{2}$ reduction of 40,800 tons and 25 tons of nitrites. Not only has the manure generated by chickens been used effectively, the approach has also provided a solution for the problem of stalk burning that farmers have always faced.

Also notable is the formation of a full industry chain. Deqingyuan's methane power generation plant achieved connectivity in 2009 with North China Power Grid, and now produces upward of 14 MW of power annually, along with 160,000 tons of organic fertiliser. In 2013, biogas sales revenue was CNY 600,000. In 2014, this reached CNY 2.7 million. The remaining liquid methane biogas residue is processed into solid and liquid organic fertiliser, with annual production of 160,000 tons of organic fertiliser sold to local farms in Yanqing and prompting the development of 10,000 Chinese mu of organic apples and 120,000 acres of environmentally friendly corn crops. Through ordered procurement, $60 \%$ of Yanqing's corn is purchased, which is then used to process into chicken feed to be fed to the 3 million layer hens at the farm. Thus a complete industry chain has been created: ecological cultivation, food processing, clean energy, equipment manufacturing, organic fertilisers, agriculture and organic planting.

Finally, there is the improvement to rural production and living conditions that has occurred. Deqingyuan transports the natural gas generated from purification and compression by tanker truck to various village facilities for tank storage. It is then sent via pipeline to countless homes. In 2013, biogas was supplied to 2000 homes, which had risen to 5000 homes by July 2014, with a further rise to 7000 homes expected. Deqingyuan and Yanqing County are co-operating in new biomass energy projects, with plans within the next three years to enable the 10,100 homes in 39 villages within Yanqing County to use biogas. During an on-site survey of the area, we found that farmers used liquid methane and remnant methane to carry out organic planting, selling the organic apples they produced to consumers, while the environmentally friendly corn was sold to Deqingyuan to raise chickens. The farmers no longer cooked, heated their homes and bathed in hot water that was reliant on crop stalks and coal, ending their high expenditure on coal. This has resulted in an enormous change to their living and working conditions.

\section{Potential for larger-scale rural organic waste energy conversion}

The first factor behind this scheme's success is the mature technology:

- Cow manure and chicken manure contain approximately $10-15 \%$ sand. In the past, due to technical restrictions on sand removal, pure chicken manure could never be used as a source for fermentation of methane gas. After Deqingyuan invented organic separation technology, achieving separation of chicken manure sand and organic materials, it was possible to extract over $80 \%$ of non-soluble solids from chicken manure.

- The methane gas produced after fermentation of livestock manure contains 2000-5000 ppm of hydrogen sulphide. Traditional methods were never able to 
solve the problem of desulphurisation. However, Deqingyuan invented bio-desulphurisation of methane gas, using sulphur-consuming bacteria to turn sulphurised hydrocarbon into elemental sulphur. It is a low-cost approach and does not generate secondary pollution.

- Conventional methane concentrations are generally $2-5 \%$. After Deqingyuan invented high-concentration methane gas fermentation technology, chicken manure fermentation and crop stalk fermentation concentration rose to 10 $15 \%$, which reduced water consumption and fermentation system area by over $50 \%$.

- Deqingyuan invented a mixed-source material fermentation technology that used crop stalks as a source of carbon, liquid methane as a source of nitrogen and fermenting microbes to achieve joint fermentation. This resolved various problems during fermentation, including saturation of stalks, floating of stalks, rapid hydrolysis of zymophytes by the stalks, as well as the need for large swathes of land. The company's membrane purification equipment uses only one-tenth of the area of similar projects, and has reduced energy consumption by over $50 \%$.

The second factor behind the scheme's success is a more reasonable economic approach:

- Investment costs are low. Deqingyuan's newly constructed daily production $8000 \mathrm{~m}^{2}$ biogas project can satisfy the residential gas use requirements of 10,000 households with an investment cost of approximately CNY 30 million, CNY 16 million lower than industry competitors.

- Gas production costs are lower. Deqingyuan, because it can collect and use the various source materials it requires from the area $20 \mathrm{~km}$ around the methane gas station, has an average gas manufacture cost of $2 \mathrm{CNY} / \mathrm{m}^{3}$, which is markedly lower than the gas price currently provided in the city of Beijing (Beijing's current natural gas station pricing is $3.28 \mathrm{CNY} / \mathrm{m}^{3}$ ).

- There has been an increase in economic value: $1 \mathrm{~m}^{3}$ of methane gas can conventionally be generated into power at a value of CNY 1.19, whereas Deqingyuan's membrane purification method enables conversion of $1 \mathrm{~m}^{3}$ of methane into CNY 2.4 worth of natural gas, thus achieving added value of $1.21 \mathrm{CNY} / \mathrm{m}^{3}$ of methane gas.

The third success factor behind the scheme's success is the greater economic utility to farmers. Deqingyuan sells the natural gas to farmers at a price of 2.5 CNY $/ \mathrm{m}^{3}$, while also accepting the crop stalks provided by farmers, converting these source materials into natural gas and costing the farmers that provide crop stalks very little actual expense. Taking a household of 3-4 people as an example, in the past, costs would be CNY 100-120 per month using tank storage liquefied gas, whereas this is now only CNY $30-40$ per month using biogas.

\section{Policy recommendations}

The first recommendation is that support for rural and small town biogas and pipeline network construction should be increased. As the pace of urbanisation and rising living standards quickens, China's natural gas consumption is entering a period of rapid growth, and natural gas supply and demand conflicts are being highlighted. If all of China's 600 million tons of crop stalks were fully utilised, annual production of methane gas could reach 120 billion $\mathrm{m}^{3}$, providing $71.6 \%$ of 2013 total natural gas consumption. Livestock 
manure can also be converted into production capacity of 122 million tons of standard coal. These organic wastes are significantly concentrated, and crop stalks are concentrated in grain-producing regions while manure is concentrated in livestock-cultivating areas. Forestry leftover materials are concentrated in forest regions, while industrial waste is concentrated in agricultural product processing plans, with the characters of the major portions being concentrated, thus facilitating promotion of rural and small and medium-sized town energy construction. It is recommended that a perspective be borrowed from energy supply and demand and from rural development, starting analysis of the issue at the level of overall national strategy and deployment in order to provide the best policy support for rural organic waste resource energy conversion.

The second recommendation is to resolve the problems faced by enterprises in energy conversion innovation. During our Deqingyuan survey, enterprises reported that some current policies do not support enterprises in innovating. For instance, there are grid connection issues. After ensuring sufficient rural gas usage, the remaining biogas has no channel through which it can be sold, and it is recommended that biogas be permitted to merge with urban natural gas pipeline networks to allow access to natural gas companies involved with urban sales.

The third recommendation relates to pricing problems. Currently, Deqingyuan's natural gas sales price is $2.5 \mathrm{CNY} / \mathrm{m}^{3}$, while Beijing's industrial user gas price is $3.65 \mathrm{CNY} / \mathrm{m}^{3}$ and transportation and shipping gas prices are even higher. It is recommended that biogas sales prices be freed up to open market competition.
The fourth recommendation relates to tax waivers. Currently, China does not provide price subsidies for biogas, and also collects 17\% VAT. Considering biogas's low carbon impact on the environment, and given that a certain amount of policy support is given to development for solar power, wind power, and biofuel energy, it is recommended that biogas be exempt from VAT.

\section{Case 5: Upstream Policy for Uncon- ventional Oil and Natural Gas}

Unconventional oil and natural gas development and production is a development trend in the majority of regions worldwide. Currently, the United States and Canada are leaders, followed by Argentina and Australia. Russia, the United Kingdom and other nations have also attempted to ensure that their shale natural gas/oil resources have potential. This paper summarises financial policies in the United States (onshore), the United Kingdom, Canada, Russia, Argentina and Malaysia, focusing on unconventional resource development incentive measures and making recommendations for China.

\section{Argentina ${ }^{1}$}

With the exception of China, Argentina has the world's largest shale natural gas resources while at the same time also being one of the nations with the most abundant shale oil resources (after Russia, the United States and China) (Nulle 2014: 60).

Currently, Argentina is implementing a special licensing rights regime. Since 1991, all licences have been managed under a special licensing fee/tax collection system, including special rights usage fees, income

\footnotetext{
${ }^{1}$ Argentina summary materials are sourced from HIS PEPS, WoodMac and Apache Enterprise website.
} 
taxes, provincial sales taxes, other signing deposits/lease amounts and oil/gas export tariffs. This system was implemented during the period of economic crisis in 2002 and has continued on to the present day.

In 2014, Argentina passed the new Oil and Natural Gas Law, prescribing special licensing usage fees and permit issuance systems controlled centrally, and also giving management rights to various provincial regulatory institutions. Prior to the launch of this approach, oil and natural gas licensing and operational jurisdiction belonged to the provincial governments. Thus provincial governments could benefit by issuing their own oil and gas rights licences.

ENARSA plays a purely commercial role, owning all unlicensed near-sea exploration on federal land within 12 nautical miles of the shore. All activities in these regions must be conducted in co-operation with ENARSA.

To describe Argentina's upstream industries as "uncertain" would be very apt. The RSC system was changed to the current licensing rights usage fee/tax regime, and the existing laws thus entirely covers the "2006 Short Law", giving oil and gas jurisdiction to provincial governments (with the exception of federal marine regions).

In order to satisfy national demand, Argentina has consistently increased use of the oil and gas industries. In recent years, energy demand has continually grown, and the government has admitted that it must become more involved, and thus it has implemented multiple investment incentive measures in the hope that the newly passed
Oil and Natural Gas Law (October 2014) will help attract investment in unconventional industries. Some particular features are:

- The bidding procedure and licensing rights usage fee system is controlled by the central government, and provincial governments are only responsible for handling oversight.

- Provincial oil and gas company preferential equity holdings in the exploration stage have been cancelled.

- Conventional and unconventional assets are differentiated, with unconventional asset development terms extended to 35 years (as opposed to 25 years) and exploration terms limited to 13 years.

- The minimum investment required to secure international prices for $20 \%$ of the crude produced was reduced to US $\$ 250$ million from US\$1 billion (for 3 years). This provides a window of opportunity for small exploration and production companies. However, analysis by Woodmac has shown that $20 \%$ of export volume over 3 years has essentially no effect on improving project IRR. Removing the 3-year restriction, on the other hand, would increase IRR dramatically.

- The Gas Plus project, which raises the price of natural gas produced using unconventional gas deposits.

- Establishment of an unconventional production permit, allowing 5 years of pilot production to establish commercial viability, and the splitting of adjacent geological concessions into units. 
- Once the pilot project stage is complete, unconventional project licensing usage fees are reduced by $25 \%$.

- Unconventional industry assessments/appraisals periods are extended (1-5 years).

- Provide $20 \%$ of export supply.

However, there are still many problems that have yet to be addressed, and resolving these could achieve a lot of what is hoped to be realised:

- Pre-emptive measures must be taken to address problems of a lack of trained labour and labour allocation. One example of such measures is the province of Neuquén, which improved shale natural gas technical capabilities by establishing an Unconventional Oil and Gas Field Technology Centre.

- Lack of an environmental regime: Because existing oil and gas fields are far from communities, there is no problem at present, but as the industry develops, problems could potentially arise.

For many reasons, it is difficult to say whether Argentina has actually succeeded in increasing unconventional sector activity, but it has certainly encouraged unconventional resource development recently, and appears to be on the right course in its efforts. However, the government must avoid the trap of intervening in current success, or it will damage the confidence of the international oil companies.

\section{Licensing Authority}

- ENARSA areas-ENARSA

- Provincial areas-Provincial authorities

\section{Regulatory Authority}

- Federal level: Energy Secretariat-Has overall responsibility for the hydrocarbons sector. Responsible for policy formulation and regulation

(continued)
- Provincial level: Provincial authority-In general, regulatory duties fall on the same person responsible for licensing

NOC

- ENARSA - Created in 2004 by Law No. 25.943. The company is owned by the government (53\%) and the provincial governments (12\%), with the remaining 35\% listed in the Buenos Aires Stock Exchange

- Most provinces have their own Provincial Companies (e.g. G\&P Neuquén)

\section{Canada $^{2}$}

Canada (one of the countries with the most abundant shale resources in the world) implements a tax/licensing rights system through provincial governments. Multiple factors determine basic system adjustments, such as contract terms, production circumstances, oil prices and so on. Even though there is no obligation to supply domestically, operators must still obtain government approval to export resources.

Canada's various provinces play a greater role by being in charge of implementing and overseeing operators. The majority of provincial governments have their own regulatory institution to carry out licensing and oversight of oil and gas operations: for example, in Saskatchewan the Oil and Natural Gas Office of its Department of Energy and Resources, and in British Columbia the Ministry of Energy and Mines and the Oil and Natural Gas Division.

Generally, with the exception of Newfoundland, no province has a NOC. In 2007, the Energy Act prescribed that Canada should have an energy company to hold and manage oil and natural gas interests. Nalcor Energy seems to have played this role, and this company has also

\footnotetext{
${ }^{2}$ In addition to HIS PEPS and WoodMac, materials relating to Canada are sourced from Manitoba and Alberta government websites as well as oil and natural gas PWC tax collection reports.
} 
co-operated in participating with Newfoundland's three marine development projects.

Essentially all governments have used licensing to capture economic lease funds -when oil prices rise, the government revenues increase, and when prices are low, the limits are adjusted. In order to avoid continual changes, a price connection mechanism was established, with the majority of governments already linking licensing rights usage fees with oil prices, production and contract years (Fig. 7.6).

According to some provincial finance systems, the licensing fee rate taxes prior to recovery of investment costs are different, allowing contractors to recover costs with relatively low risk. There are also some provinces that implement multi-tiered fee rates based on rates of return, thus forming a tiered mechanism.

\section{Canada's Provincial Institutions}

- British Columbia Ministry of Energy, Mines and Petroleum Resources-The Oil and Gas Commission

- Saskatchewan Ministry of Energy and Resources-Petroleum and Natural Gas Division

- Minister of Energy-The Alberta Energy Regulator

- Department of Aboriginal Affairs and Northern Development Canada (AANDC) - Northern Oil and Gas Branch of the AANDC

- Canada Nova Scotia Offshore Petroleum Board

- Canada-Newfoundland and Labrador

Offshore Petroleum Board

- The Ministry of Energy in Alberta

- Department of Energy, Mines and Resources of Yukon

- Ministry of Natural Resources in Québec

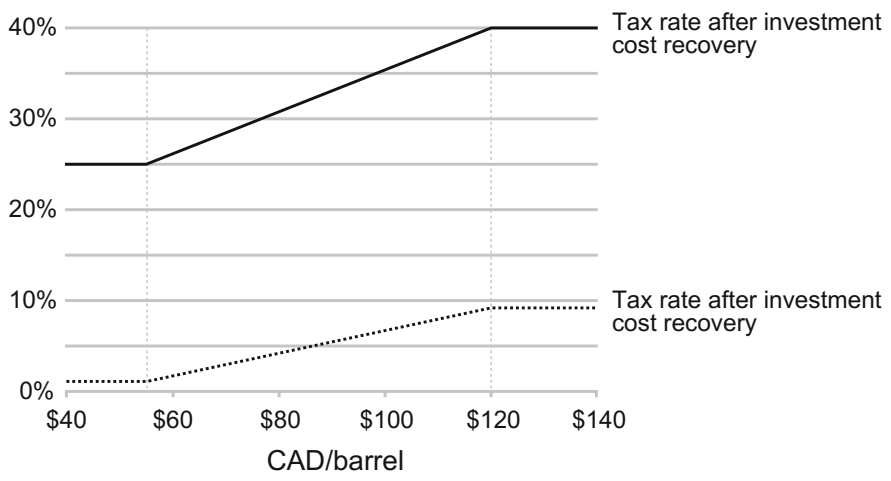

Alberta licence usage free structure

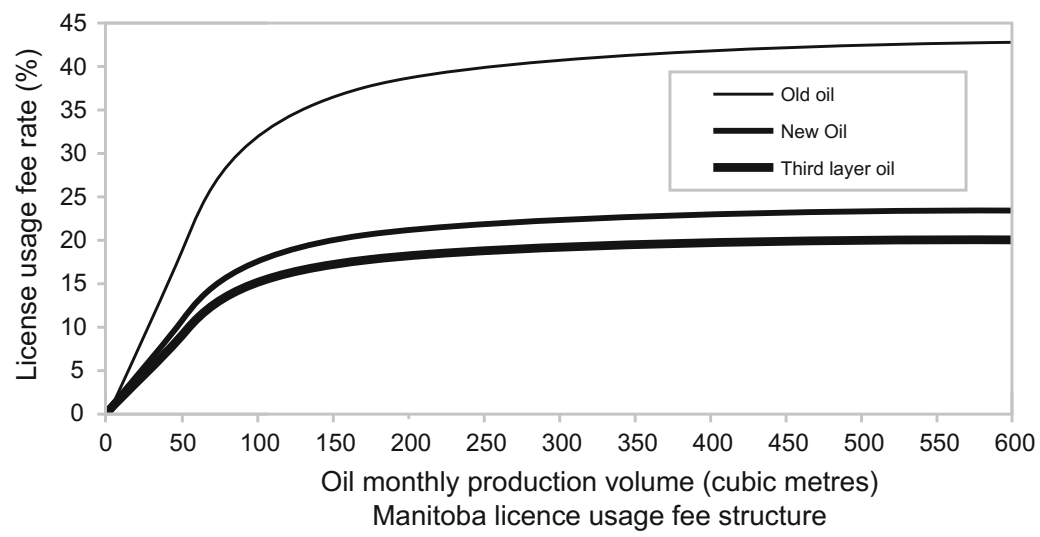

Fig. 7.6 Licensing rights usage fee structure 
Canada's three tiers of taxes:

- First tier: Federal income tax collected for "taxable income" from oil and natural gas projects.

- Second tier: Provincial income tax (differentiated from federal taxes by the different tax-exempt amounts for each province) collected for "taxable income" from oil and natural gas projects.

- Third tier: A provincial and national resource tax collected for ownership rights of Canada's resource assets. In order to allocate some tax amounts to the provincial governments, the federal tax has a $10 \%$ exemption. These exemptions are only applicable to income generated within Canada.

Like many countries, Canada has taken a very active role in terms of policy, and is very willing to use tax exemptions/ reductions/offsets to provide correct incentives. Currently, overall measures taken are as follows:

- Early-stage $10 \%$ Investment Tax Credits (ITCs) for oil and natural gas projects.

- Provide other ITCs for scientific research and experimental development (SRED) activities to incentivise industry innovation.

- Unused tax offsets can be carried forward over 20 taxation periods.

- Unconventional projects enjoy higher capital cost subsidy rates, directly affecting the taxes that contractors pay.

- Implemented programmes include encouragements for tight natural gas and shale natural gas development net profit licensing rights, low production capabilities usage fee reductions, oil sand usage fee programmes, marginal oil field usage fee programmes and so on. These are aimed at satisfying special needs related to resources and/or geographical restrictions, and many other programmes are available.

In order to encourage innovation, the Canadian government connects oil prices to production and usage fee structures, along with various tax exemptions, which play an important role in upstream industry development. For example, the development of steam-assisted gravity drainage technology was highly beneficial to oil sand projects.

\section{Malaysia}

Malaysia has a series of highly optimised and stable systems that implement various financial terms based on production volume share contract (PSC) terms - the most recent revenue-over-cost PSC contract conducting licensed business (Fig. 7.7).

In conjunction with IOCs, Malaysia's Petronas uses an exploration and development subsidiary (Petronas Carigali) as a joint venture enterprise investor (sometimes as operator) to participate in upstream industry activities. In addition, it also uses the subsidiary company MPM to act in a regulatory capacity, overseeing all of the nation's upstream industry activities. According to PSC requirements, IOCs and operators (including Petronas Carigali) pay usage fees and taxes to MPM and the local government. In the majority of contracts, Petronas Carigali holds incidental interest rights to all exploration regions, generally between 15 and 25\% (negotiable).

Recently, Malaysia has introduced a Risk Service Contract (RSC) to increase activity both in mature fields and in stranded fields.

Recently, Malaysia has begun implementing risk service contracts (RSCs) to strengthen the development of oil and gas fields and latent oil and gas fields. This includes terms that not only protect 


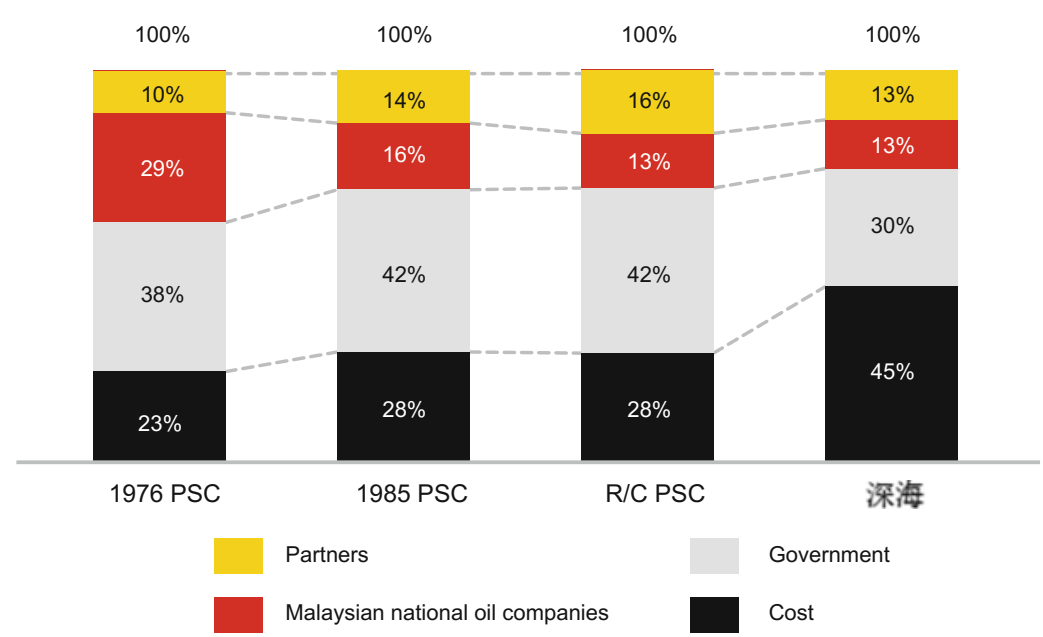

Fig. 7.7 Malaysia production share contracts. Note In 1976 and 1985, R/C production share contracts were based on 40 mmboe reserve volume. Moreover, deep-sea production share contracts assume oil volume of over 1 bnboe

contractors from downside risk but also limit the upside. (It should be noted that Petronas is not permitted to sign this type of contract. The contract's main purpose is to encourage and cultivate local Malaysian enterprises to participate in upstream oil and natural gas projects).

The potential for Malaysia in unconventional resources has not yet been recognised, and the country is in the process of learning from the experience of other nations (Australia and Canada). In fact, recent industry reports state that Petronas could be able to partner with US company Hess to assess and learn how to develop China's unconventional resources/shale oil or shale natural gas.

As cost structures change, or when new cost structures arise (as was the case with marine oil), Malaysia's government adjusts Petronas's and its own proportions of ownership to achieve a balance. At different periods, the government has used a variety of mechanisms, including reductions to taxes and usage fees, acceleration of depreciation, reduction of export tariffs and so on, to attract more investment. In 1985s revised version, there were many adjustments that improved the rate of cost recovery, adding to the profits of contractors while encouraging exploration and development of small gas and oil fields found through earthquake research. At the same time, Petronas's participation became mandatory, allowing it to play a larger role. In 1991, the government launched marine oil incentive measures and subsequently signed revisions of contracts with more attractive terms for two oil fields with Mobil Oil, exhibiting the pragmatic style of the government and regulatory institutions. The increase in contractor profits and the proportion of cost recovery, as well as reductions in taxes and export tariffs, have raised revenue proportions for these contracts, prompting development of marine oil.

In terms of adjustment to financial terms in the macro environment, Malaysia has always been very pragmatic and flexible. When appropriate, it will take suitable measures to attract more investment and 
turn standard PSC development into R/C $\mathrm{PSC}$, increasing average purchase promotions of contracts and enabling one to see Malaysia's time arrangements during a transitionary period. The pragmatism of Malaysia is also seen at appropriate times when the country is expanding state projects and encouraging commercial structures, and the country does not use a general structure (for example, an enhanced oil recovery project increased production of mine oil and used relatively relaxed rules).

\section{Russia $^{3}$}

Russia currently has many types of contract. They are briefly summarised below:

- Government reserve: A financial system based on export taxes and mineral extraction taxes-usage fees (also called "licensing rights").

- Government control: Terms of 5-725 years (according to "Underground Law") for underground exploration and/or exploration or production licences that are distributed through auction or tender.

- Product share agreements (PSAs): Even though such agreements do still exist in Russia, they should no longer be part of any new project contract templates, now that the PSA law has been revised.

- Strategic Industry Law and "Underground Law" amendments regarding "strategic oil and gas fields": Russia's institution in charge of underground management is Rosnedra, which comes under the country's Ministry of Natural Resources. Rosnedra is responsible for managing all issues related to the issuing and revocation of permit, as well as licensing.

- NOCs: NOCs (Gazprom, Rosneft and Zarubezhneft) have special status. Gazprom monopolises pipeline exports and must hold at least $50 \%$ of shares in offshore projects. In fact, infrastructure is monopolised by Gazprom and Rosneft.

Whether or not a project is approved is determined by project type-foreign company direct licensing and foreign company shares in Russian companies, as well as joint ventures between foreign and Russian companies, are each restricted by a specific category of laws.

In order to encourage the commercialisation of unconventional resources, Russia has implemented several financial and regulatory incentive measures to attract investment in the sector:

- Starting with a resource consumption deduction of $1 \%$, a 15 -year zero mine tax and reduced remote-region export tax, as well as an extension of exploration permit periods from 5 to 7 years, have been implemented.

- Profit-based taxation for some projects and a complete revision of the licensing system for unconventionals is currently under way, as well as the introduction of finance terms to attract investment into Russian unconventional resources. Russia has among the most abundant reserves of unconventional resources of any country, and this approach could be slowed due to recent sanctions placed on Russia by the West.

\footnotetext{
${ }^{3}$ In addition to HIS PEPS and WoodMac, reference was also made to Shell reports on Russia.
} 
- In order to support conventional resource development, VNIGUI, VNIGNI and the Shpilman Research Institute are in the process of studying the legal status of unconventional resource projects in Russia-definitions, resource types, reserve reports, permit issuances, commitments and regulation.

Some traditional problems, such as local authorities presenting complex processes and bureaucracy, continue to cause foreign investment to be hesitant to enter Russia. Based on macro environment changes, Russia's systems are also continually changing. One example is that after a new law was passed in December 2013, private companies obtained the right to export LNG.

\section{United Kingdom ${ }^{4}$}

As a country whose oil sector is relatively mature in its development, the United Kingdom is continuing to implement simple licensing usage fee/tax regimes. Currently, special licensing only exists in Northern Ireland, with all other regions already essentially being purely tax regions. Unconventional resources follow similar systems to conventional resources, but there are also special exemptions aimed at encouraging their development.

Through the newly established Energy Development Unit, the United Kingdom's DECC issues production, exploration, and development licences, which provide operators with well drilling/development permissions and construction permits for exploration and production activities. Well drilling/development and construction permits are issued by local authorities, and require interaction between various local government institutions.
Unconventional activities are relatively new (compared to the United States) and management methods await further improvement. Mineral resources are all state assets, but an industry group, UKOOG, wishes to launch a new method of compensating the communities affected by the shale gas operations, involving fixed fees and a linkage to total revenue. This model has been welcomed by the UK government.

In 2003, all oil and gas field usage fees were discarded, with post-2003 approved oil and gas revenue taxes being annulled. Oil and gas income taxes approved after 2003 were waived, and in 2006, as the oil price rose, surcharges were introduced. In addition, since the price environment was not sufficiently attractive, various types of tax exemption were introduced. All of this shows that the UK government took active and timely measures to intervene. Furthermore, based on different oil and gas field history, the United Kingdom has different tax collection structures, thereby achieving lease fee risk sharing through a positive balance between government and operators.

With regard to unconventional resources, the following incentive measures have already been announced:

- for surrounding supplementary expenditure applicable to scope expansion for shale and unconventional oil and gas resources - an extension of the loss structure carry forward period to 10 accounting periods (originally 6); and

- "pad" subsidy for shale projects (the definition of a "pad" is a well and mining area; a portion of generated revenue is exempted from the surcharge, reducing the tax rate from 62 to 30\%) (Fig. 7.8).

\footnotetext{
${ }^{4}$ In addition to HIS PEPS and WoodMac, material sources
} also include the DECC and UKOOG websites. 


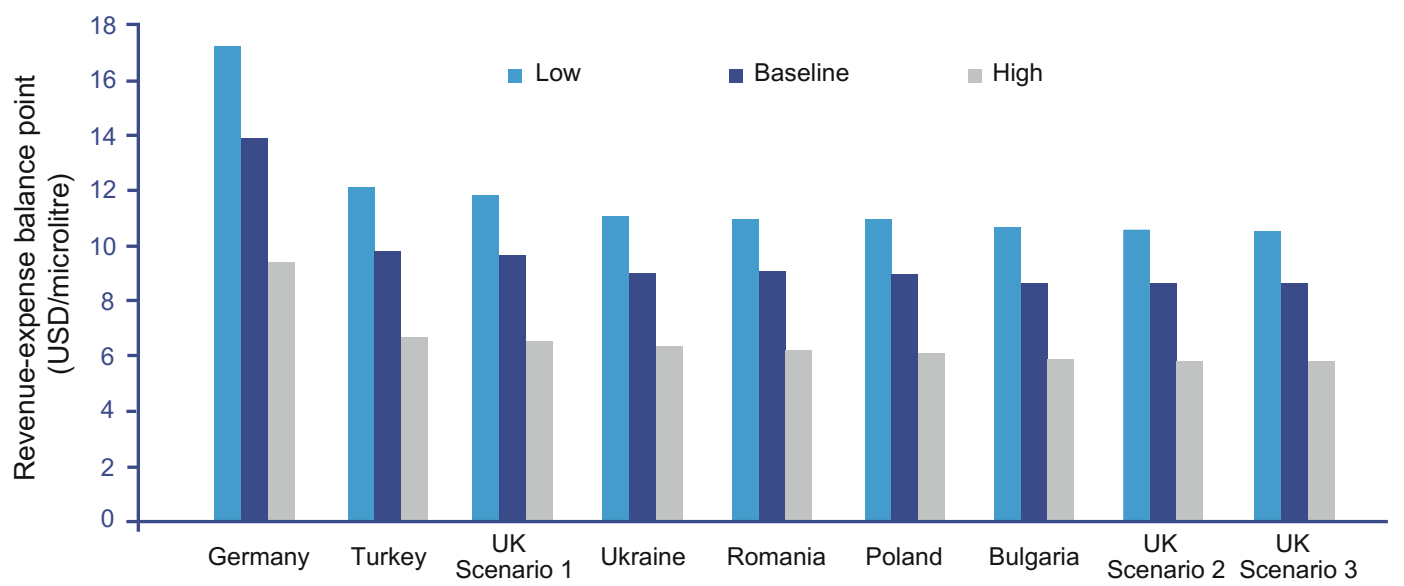

Fig. 7.8 UK shale finance system competitiveness (Woodmac study)

Wood Mackenzie used the Namurian shale region cost hypothesis (as well as three cases of oil well production capacity) to carry out an analysis of the new conditions and calculate product break-even price (the pad has five producing oil wells, and another five will begin production in five years). The scenario's configuration is essentially based on three different tax circumstances:

- the current land permit regime (not including small oil field subsidies);

- a new pad allowance based on 50\% of all capital expenditure - this expenditure can be used to offset payable SCT from profits over the following five years, and all subsidies can be carried forward;

- a new pad allowance based on $75 \%$ of all capital expenditure - this expenditure can be used to offset payable SCT from profits over the following year, and all subsidies can be carried forward.

However, negative appraisals still exist, and the government is currently solving these. It is now permitted to transfer cross-pad exemptions from failed pads to successful pads (though this must be done within three years), and it is also permitted to replace operating asset development discounts (in the early stages companies could not implement oil/natural gas sales revenue development periods unless there was reinvestment into the British mainland shelf). Subsidies can be used to pay capacity fees and fair trade expenses.

Financial incentive plans have improved the competitiveness of British shale natural gas in Europe. However, oil well efficiency and local approval process simplification are keys to the success of British shale natural gas. 


\section{UK Regulatory Framework}

- Minister of Energy and Climate Change: Oil permit licences are issued following a decision by the minister

- DECC: Responsible for the issuance of oil licences, with specifics overseen by the EDU

- UOGO: UOGO is DECC's internal unconventional oil and gas activity direct point of liaison

\section{United States-Mainland ${ }^{5}$}

Unlike other countries, land owner mineral asset resources ownership rights are the foundation of the US upstream industry investment regime. In the majority of cases, this means that mainland resource ownership rights belong to the individual, and thus there are no licence-issuing institutions and only private leasing. For federal and state land, the government will issue lease agreements based on direct tax collection and usage fee systems.

The United States works on a federal system, and thus the majority of laws and regulations governing the oil and natural gas industry are determined and implemented by the states. The federal government is responsible for federal lands (namely federal water regions such as the Gulf of Mexico (GOM)) and interstate trade, including interstate pipelines. The US government's regulatory systems (state and federal) are relatively optimised and efficient.

Historically, US regulatory systems have created an overall environment and then a series of conditions that support private investment development. In order to support mining industry development, the United States has consistently avoided nationalisation. The current shale revolution is also a result of this overall environment.

After eliminating the price controls on natural gas and its shipping (deregulation), the United States began to rely on the market to satisfy demand (increased supply). Shipping capability rights and pipeline ownership rights are separated, allowing producers to compete with pipeline capacity.

Interestingly, the US government offers direct support for public research and development expenses. For example, the primary goal of the Eastern Shale Gas Project (1975-1992) was the development of shale natural gas production technology. The United States also offered direct funding support for several industry pilot programmes such as the first multi-break horizontal well in 1986. It also gave its assistance to the 1991 hydraulic fracturing law in conjunction with water level wells company Mitchel Energy. After several decades of stable industry development, US technology and professional assistance is far ahead of the rest of the world's oil and natural gas industries (the United States has the world's largest quantity of well exploration equipment).

Based on the positive experiences of the United States, some recommendations are (based on Nulle 2014):

- flexible land transfer rules and flexible commercialised statement requirements;

- advance provision of reliable pipeline and shipping infrastructure usage rights;

- implement free prices and guarantee prices;
${ }^{5}$ In addition to HIS PEPS and WoodMac, reference was also made to Nulle (2014), the Eenergy website news section and Daniel Johnston's work on financial terms. 
- import expert labour and equipment capabilities;

- encourage high-cost/risk unconventional development tax regimes;

- provide direct R\&D support, and improve geological and technological knowledge and skills;

- enable free return of profits to investors; and

- stability in terms of laws and policies.

The US government's measures have seen broad success, but it is worth noting that this success was obtained only after a long period of time, and was the result of multiple policies (financial incentives, R\&D funding support, deregulation) and structural elements related to the US economic and regulatory system (capital availability, mine asset private ownership (land owners also benefit), stability, high degree of professional technology and experienced human capital, existing pipeline capacity tenders and so on).

\section{Effects of Financial Incentives}

The federal government implements specific policies for unconventional resources, and these policies were launched in 1980 and expired in 2002. The Crude Oil Windfall Profit Act played an important role, for example in offering subsidies to unconventional resources developed from shale natural gas and in the formulation of the "Intangible Development Cost Expenditures" provisions, which permitted producers to write off a large portion of development costs as expenses. The government's share of revenue derived from primary producers on the Outer Continental Shelf of the Gulf of Mexico is very low. Indeed, because of fee usage refunds and tax offsets, there is an effective $0 \%$ royalty rate

\section{Recommendations for China}

\section{Encourage provincial/community management of shale oil/gas}

development and production: In the United States, Canada and Argentina, local authorities/governments play a critical role and for a period of time there are direct regulatory institutions. Sometimes, provinces (such as in Argentina) will invest in partnerships and form joint venture enterprises (rather than being an "incidental" partner).

2. Implement low licensing usage fees/tax rates for unconventional natural gas to provide tax reductions and exemptions: In some countries (such as Canada), tax rates are linked to actual oil prices, and this allows investors to know what the tax burden is at different oil price levels without having to adjust strategy based on changes in oil price. For example, Russia is currently considering a cancellation of unconventional oil/natural gas mineral extraction tax, and mineral extraction tax is a significant tax burden for Russian companies. Other tax leverages include tax carry forward (such as in the UK).

3. Extend unconventional oil and gas field small-scale trials, exploration and production terms: Formulate transition timetables. In the majority of countries, shale oil/gas field licences are extended for 5-10 years.

4. Deregulate, and introduce competition mechanisms: Provide reliable pipelines and shipping infrastructure usage rights in advance and cancel price controls, which is believed to be the key to the US's success. In particular, separate shipping infrastructure usage rights from pipeline ownership rights, allowing producers to compete over pipeline capacity.

5. Support development of dedicated operation companies: The government 
plays a unique role in development R\&D and in supporting dedicated operation enterprises. These companies can provide effective assistance to accelerate the development and production of China's shale natural gas/oil. To this end, the government should support the development of Chinese companies or foreign professional technology companies, with particular attention given to the growth and development of small-scale enterprise, which plays a vital role.

\section{Case 6: Mexico Oil and Natural Gas Industry Upstream Opening Policies}

In 2013, Mexico revised its national constitution in an attempt to revitalise its oil and natural gas industry. Mexico's government took specific and transparent measures to promote Bid Round Zero. During this period, Pemex submitted an application and obtained $83 \%$ of proved oil field/natural gas field mining rights and $21 \%$ of unproved oil/gas area exploration rights. This was viewed as an effective and practical method to balance the nation's overall interests and the interests of the country's oil companies. At the same time, it also offered sufficiently attractive opportunities for foreign business and private investors.

It is recommended that China use the Round Zero procedure to enable existing licensed state-owned oil companies to name portions they wish to hold and the portions that can be provided to new investors, thereby prompting investment and in the mid- to short-term accelerating change in unconventional energy shale natural gas production volume. Using this approach, China could improve non-renewable energy structure usage efficiency for natural gas while at the same time controlling the degree of reliance on foreign imports - which has already grown from $0 \%$ in 2005 to $32 \%$ in 2013.

\section{Mexico prior to 2013: awaiting change}

Mexico's oil industry history is very long, with oil discovered for the first time back in 1904. Production volume had reached 150,000 barrels/day by 1917 . The IOC likewise rapidly joined, helping to raise oil production volume. By 1921, Mexico's oil daily production had exceeded 530,000 barrels, accounting for one-fourth of the world's total production volume. However, fierce disputes between unions and the IOC ultimately led to Mexico nationalising all assets of the IOC in 1938, and through this establishing a NOC. Since then, PetroleosMexicanos (Pemex) has always been the sole rights holder of Mexico's oil and natural gas resources.

For more than 70 years, Pemex had operated its own oil and natural gas business under the ISC. Such a monopolising national oil company has gradually become sluggish, partly because budget and financial management has been tightly controlled by Mexico's Ministry of Finance and Public Credit. As seen in the diagram, Pemex's production volume reached its peak in 2004-2005, with daily oil output of approximately 3.6 million barrels, and daily natural gas production of approximately 3 billion $\mathrm{ft}^{3}$. Since 2004, 
production volume continuously dropped, and the prospects appeared bleak. WoodMac made forecasts of rapid decline in production volume over the following several years. Mexico was then awaiting change.

In order to relieve production volume declines, Mexico launched an energy policy reform in 2008, allowing Pemex to outsource some mature marginal oil, gas fields and service contracts. The IOC was not particularly enthused. In 2011, Pemex licensed out production volume based on oil and gas fields in two service contracts to French company Schlumberger and UK company Petrofac. In 2012 and 2013, Pemex again held two service contract tenders and still only attracted international service companies (Fig. 7.9).

Deep Water Bay, Mexico has consistently been a major success story for the US oil and natural gas industry. Deep Water Bay, Mexico is on par with West
Africa and Brazil and is known as the world's golden triangle for exploration and production. However, despite having the majority of jurisdiction over the GOM, Mexico is essentially behind all other industry participants, and has conducted no production of deep water oil/natural gas.

Recently, the US shale natural gas/oil revolution has been another jolt to Mexico, since a portion of the shale oil/gas distributed in Texas should, from a geological perspective, extend into Mexico.

The Mexican government and Pemex have realised that radical change is needed and that the time has come to start a new chapter in the history of oil and gas in Mexico.

\section{Energy reforms in 2013 with the rise of a new president}

On December 1, 2012, Enrique Peña Nieto became president of Mexico. His party PRI beat the PAN to win the presidency.

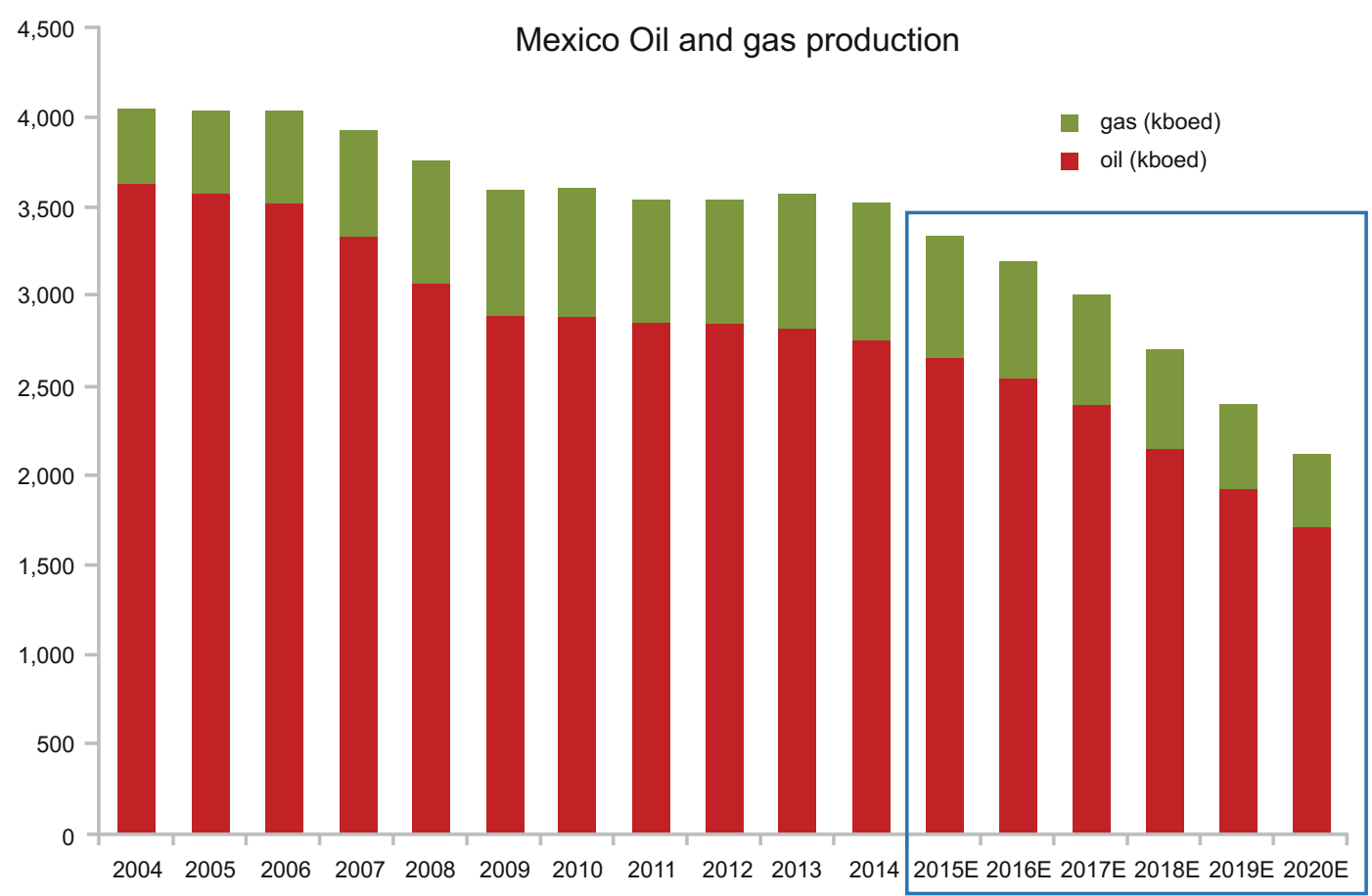

Fig. 7.9 Mexico oil and gas production 
The PAN had been the ruling party from 2000 to 2011. The PRI had controlled Mexico since 1928, ruling for 71 years.

In August 2013 President Nieto submitted an energy reform bill with a total of 27 specific laws to the Mexican congress. The congress had to pass the bill and execute reforms. By December 2013, Mexican law prescribed that once again it was permitted for international oil companies and private investors to invest in oil and natural gas through three types of contracts: service contracts; production volume or profit-sharing contracts; and licence contracts (Fig. 7.10).

\section{Round Zero: Balance between pro- tecting national oil company interests and attracting foreign investment}

Pemex, in terms of the overall oil industry, is far behind China. China has multiple national oil companies, including the top three, CNPC, Sinopec and CNOOC. These three companies are all listed on the NYSE.

In order to use Pemex equity to protect overall national interests, in 2014 the Mexican government took the unique approach known as "Round Zero". Pemex had to submit its choices for retaining and abandoning oil and gas fields prior to March 2014. The government's regulatory institution energy minister and CNG had six months to decide which oil fields/Pods would be retained by Pemex. In order to retain any production assets, Pemex had to explain its capabilities in the application regarding technology, assets and operations. In terms of exploration area, Pemex likewise had to show that it had explored wells and/or was currently exploring underground areas.

Based on estimates by the $\mathrm{CNH}$, the result of Round Zero was that Pemex retained approximately $83 \%$ of proved reserves ( $2 \mathrm{P}$ reserves), as well as $21 \%$ of

\section{Round 0 outcome for Pemex before opening of Mexican energy sector for IOCs}
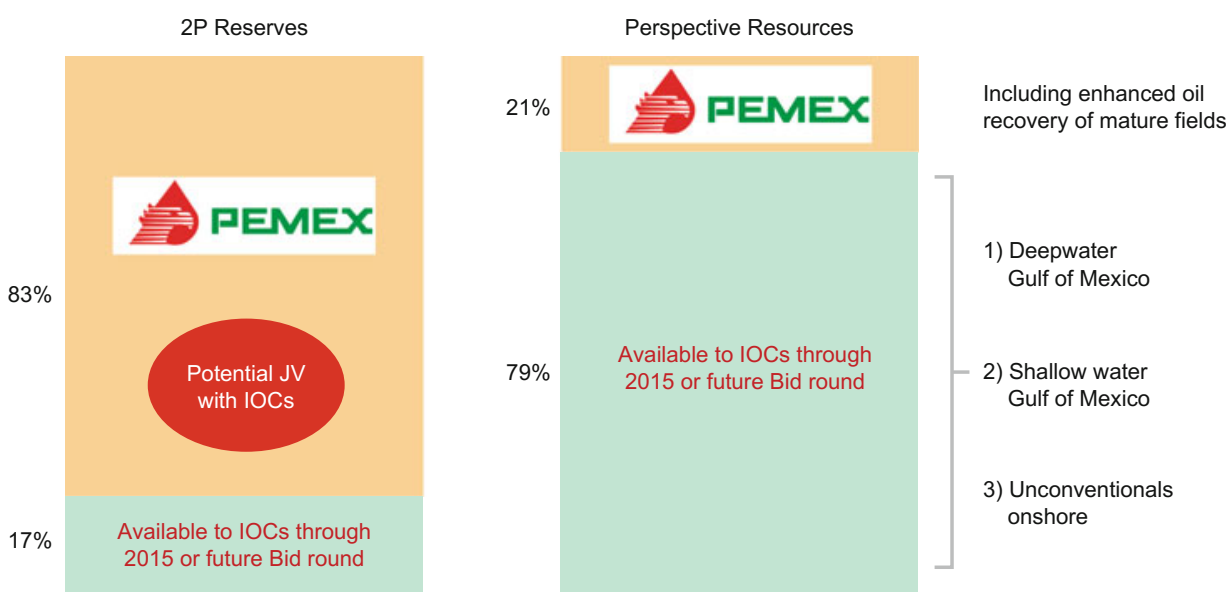

Fields/blocks awarded in Round 0

Fig. 7.10 Mexican NOC prior to reforms 
unproved reserves. For the held assets of Pemex, this still allowed it to invite foreign investment and transnational companies to co-operate in exploration/development/ production.

\section{Mexico's Round 1 Bid Round: What to expect in 2015?}

Since December 2014, the CNH has begun to carry out the first round of bidding in stages, including for shallow water exploration, shallow water development, land and major production field Chicontepec capital injections, unconventional energy and deep water. The $\mathrm{CNH}$ has continued to invite potential international investors to participate in the Round 1 Bid Round.

Since June 2014, the drops in oil prices have forced the Mexican government to reconsider whether or not to make 2015 the year to attempt attracting international oil company investment. The current decision appears to be to carry out all bidding rounds according to plan, including the most attention-grabbing deep water portion. The date for completion of bidding is reportedly mid-July 2015 . Leading international oil companies, including Chinese national oil companies (such as CNOOC) and other foreign national oil companies, are expressing great interest in this first round of bidding in Mexico. There is still some concern within the industry about whether Mexico will continue to fully control and occupy the oil/natural gas assets, whether there will be major changes to Pemex and whether there will be attractive financial terms for major deep water regions so as to accelerate exploration and mining of deep water oil and gas in Mexico.

Of course, the industry has also consistently recognised the speed and determination of the Mexican government in its energy reforms, as well as its detailed and transparent approach. This includes the Round Zero opening up of over $20 \%$ of proved reserves and $80 \%$ of unproved reserves to international oil companies.

It is worth considering whether these methods are suitable to China, especially given its attempts to accelerate unconventional energy and shale natural gas exploration and development and to speed up progress attracting suitable international oil companies and private funding.

Another issue the oil and natural gas industry should consider is whether Mexico can maintain its open policies if there is a leadership change after Nieto's six-year term (see Fig. 7.11).

\section{Mexico Round Zero bidding reform prospects}

\begin{tabular}{|l|l|l|l|l|l|}
\hline & $\begin{array}{l}\text { Shallow water } \\
\text { bay: exploration }\end{array}$ & $\begin{array}{l}\text { Shallow water } \\
\text { bay: development }\end{array}$ & Land & $\begin{array}{l}\text { Chicontepec region } \\
\text { and unconventional }\end{array}$ & $\begin{array}{l}\text { Deep } \\
\text { water } \\
\text { bay }\end{array}$ \\
\hline $\begin{array}{l}\text { Project date of } \\
\text { announcement }\end{array}$ & December 2014 & January 2015 & $\begin{array}{l}\text { February } \\
2015\end{array}$ & March 2015 & $\begin{array}{l}\text { April } \\
2015\end{array}$ \\
\hline $\begin{array}{l}\text { Data centre date } \\
\text { of establishment }\end{array}$ & January 2015 & January 2015 & $\begin{array}{l}\text { March } \\
2015\end{array}$ & April 2015 & $\begin{array}{l}\text { May } \\
2015\end{array}$ \\
\hline
\end{tabular}




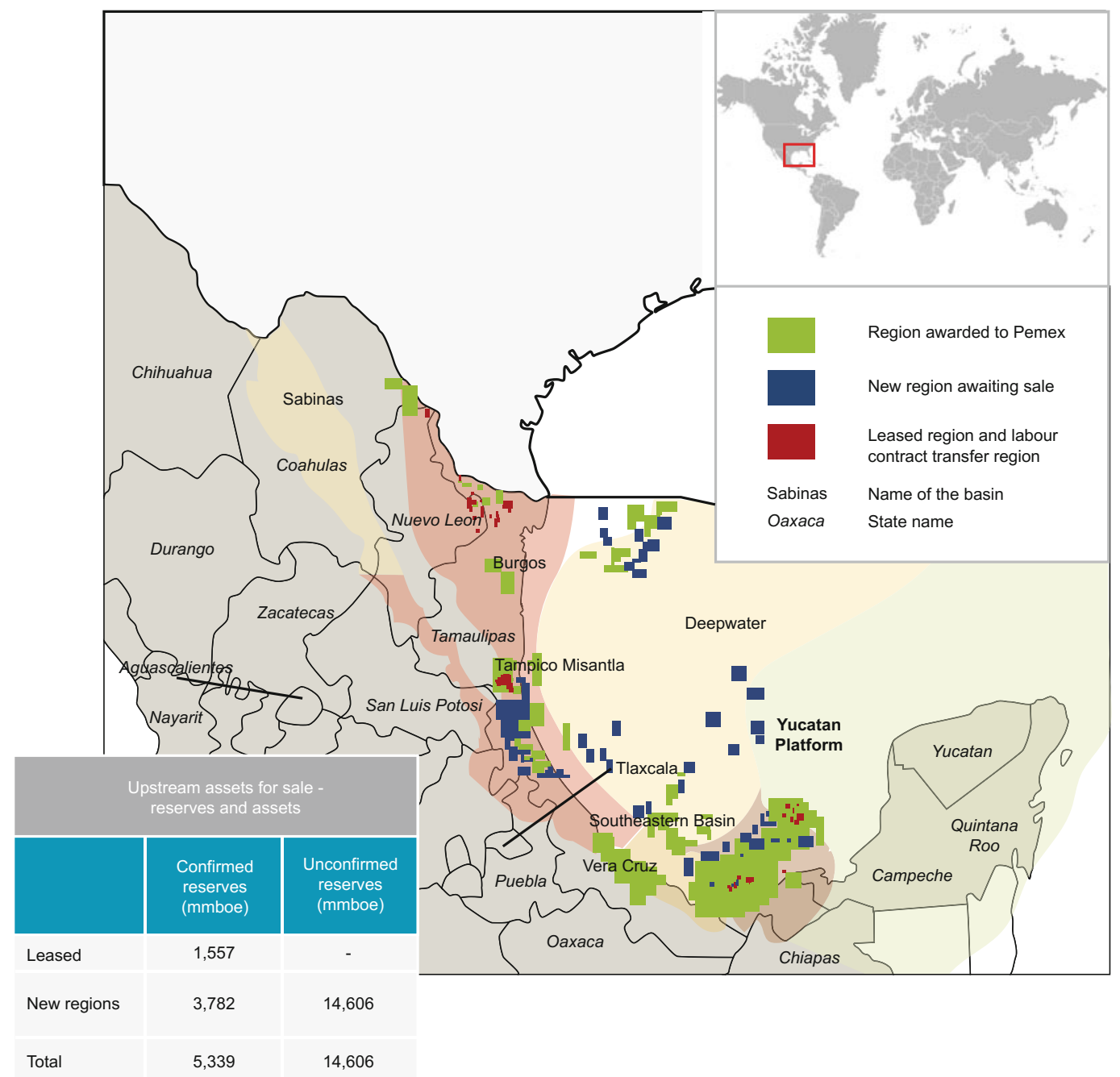

Fig. 7.11 Mexico's Round Zero reform prospects

\section{Case 7: Analysis of the Approach to Opening Up Upstream Industries in Oil and Natural Gas in Various Countries}

Generally speaking, the opening up of a country's oil and natural gas industry is closely linked to its natural resources and its development strategy. For example, in an oil and natural gas-exporting nation with abundant resources and good mining conditions, the terms on potential investor contracts will be stricter. Thus in Saudi Arabia, oil exploration and development are essentially not open to outside interests. Instead, Saudi Arabia hires international service companies to provide their oil industry with technical services. In importing nations with few resources and difficulties with mining, the degree of openness is greater. For example, in the United States, Canada, the United 
(E) TSA

Fixed margin

PSC

Tax royalty

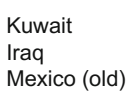

UAE

Nigeria (onshore) Venezuela
Indonesia

Russia

Brazil

China

Angola

Nigeria (offshore)

Mexico (new)

Fig. 7.12 World natural gas upstream openness

Kingdom, Australia and other OECD nations, oil and natural gas upstream industries are entirely open. The tax and royalty system between the nation and states/provinces ensures that their interests are protected. In terms of shale natural gas, US private land owners can also discuss royalties from the engaged company (Fig. 7.12).

Upstream contract terms are of four types, from stringent to loose:

\section{- Service contracts (or Technical Ser-} vice Agreements (TSA), Enhanced TSA): Countries employing this approach are primarily countries with very abundant oil and gas resources, such as Qatar, Iraq and Mexico. International oil companies and international service companies are each able to apply for these terms. However, Qatar and Iraq only employ international oil companies, using their comprehensive management for oil and gas development. It is worth noting that in recent years Mexico only used service contracts, but has been unable to change its precipitous slide in oil and gas production. They are therefore in the process of using new and more attractive contracts to attract foreign investment and technology, especially in deep water oil and gas exploration and development.

- Fixed margin contracts: Some countries, such as the UAE and Nigeria (mainland), have used a special contract term approach. For each barrel of oil produced, the foreign party obtained a fixed return, for example \$1 per barrel. This term's downside for foreign parties is a low rate of return, but the benefit is that there is very little investment risk and a high degree of certainty. For the country in question, this term's greatest weakness is that it encourages cost controls by investors.

- Production sharing contract (PSC): In 1972, Indonesia led the way in proposing PSCs. This is an international approach, and in particular a popular approach in third-world countries, that encourages foreign investment. It caters for the interests of both the country in question and the foreign parties. Investors generally assume all exploration risks and expenses. Prior to the discovery of commercial opportunities, they receive their reward by recovering investments and production 
volume sharing. It is worth noting that investors see large differences in shared proportions, and the recovery factor (also known as the R-factor) determines the differences.

- Tax and royalty: In Western countries such as the United States, the United Kingdom, Canada, Australia and others, domestic oil companies and foreign oil companies are essentially competitors on the same playing field. On average, tax systems offer investors rates of return that are slightly higher. However, this also depends on the degree of taxation. Some countries, such as Canada, use a tax rate that is linked to international oil prices, which enables investors to have a measure of certainty regarding investment risk. However, tax systems are not equivalent to a loss of control by the country in question. Using a tax system still allows the nation to continue to play an important role, especially in signing off on oil and gas exploration and development licences, approval environments and safe production plans. The country can also use increases or decreases in tax rates to encourage or inhibit a given direction of development.

In summary, the more oil and gas resources there are, the more that nations tending to export will prefer to use TSAs. Moreover, in oil and natural gas-consuming nations, countries with open markets tend toward using tax and royalty methods. Some countries such as Nigeria offer fixed-return contracts where land development is not particularly difficult and risk is low, and offer production volume sharing contracts for marine oil mining where there is higher difficulty and greater risk.

In China, conventional oil and gas sectors use relatively general production sharing contracts. Shale natural gas is buried deeper, there are greater difficulties and costs in its development, and it is sold domestically. If it is hoped to attract more domestic and foreign investors to join in shale natural gas exploration development ventures, then a reasonable improvement would be to offer PSC or tax and royalty systems that are more attractive than China's existing production volume sharing contracts.
Open Access This chapter is licensed under the terms of the Creative Commons Attribution 4.0 International License (http://creativecommons.org/licenses/by/4.0/), which permits use, sharing, adaptation, distribution and reproduction in any medium or format, as long as you give appropriate credit to the original author(s) and the source, provide a link to the Creative Commons license and indicate if changes were made.
The images or other third party material in this chapter are included in the chapter's Creative Commons license, unless indicated otherwise in a credit line to the material. If material is not included in the chapter's Creative Commons license and your intended use is not permitted by statutory regulation or exceeds the permitted use, you will need to obtain permission directly from the copyright holder. 